\title{
Hydrogen Production Performances via Steam Reforming over Hydrotalcite Derived Catalyst: A Sustainable Energy Production Review
}

\author{
M. A. Salam¹", T. Hossain1, N. Papri1, K. Ahmed1, M. S. Habib1, M. S. Uddin¹, R. S. Wilckens² \\ ${ }^{1}$ Hydrogen Energy Laboratory, BCSIR Laboratories Chittagong, Bangladesh Council of Scientific \& Industrial Research (BCSIR), \\ Bangladesh \\ ${ }^{2}$ School of Chemical Engineering, College of Engineering and Physical Sciences, University of Birmingham, United Kingdom \\ Email: *salam.bcsir@gmail.com, *salam.ctg@bcsir.gov.bd
}

How to cite this paper: Salam, M.A., Hossain, T., Papri, N., Ahmed, K., Habib, M.S., Uddin, M.S. and Wilckens, R.S. (2020) Hydrogen Production Performances via Steam Reforming over Hydrotalcite Derived Catalyst: A Sustainable Energy Production Review. Advances in Chemical Engineering and Science, 10, 259-296.

https://doi.org/10.4236/aces.2020.104018

Received: May 7, 2020

Accepted: August 30, 2020

Published: September 2, 2020

Copyright $\odot 2020$ by author(s) and Scientific Research Publishing Inc. This work is licensed under the Creative Commons Attribution International License (CC BY 4.0). http://creativecommons.org/licenses/by/4.0/

\begin{abstract}
The review outcome represents the optimum catalytic conditions for the production of hydrogen using hydrotalcite derived catalysts. It covers dry and steam reforming of methane, steam reforming of methanol and ethanol to hydrogen. The review also revealed the specific properties of hydrotalcite derived catalysts for the reactions. Among catalyst investigated, Ni \& Fe promoted Al-Mg containing hydrotalcite catalyst perform best (99\%) for dry reforming of methane at $250^{\circ} \mathrm{C}$. For steam methane reforming, Ni containing ca-aluminates hydrotalcite catalyst act as the best $(99 \%)$ at $550^{\circ} \mathrm{C}$. Cu-supported $\mathrm{Zn}$-Al-containing catalyst performs the best (99.98\%) for steam reforming of methanol at $300^{\circ} \mathrm{C}$ whereas $\mathrm{Cu}$ impregnated $\mathrm{Mg}$ - $\mathrm{Al}$ containing hydrotalcite is the best (99\%) for steam reforming of ethanol at $200^{\circ} \mathrm{C}-600^{\circ} \mathrm{C}$. It's (HT) tunable and versatile textural and morphological properties showed excellent catalytic performances for different industrial processes and in sustainable hydrogen production.
\end{abstract}

\section{Keywords}

Hydrogen, Hydrotalcite-Derived Catalyst, Catalytic Performance, Promoters

\section{Introduction}

The demand for fuel is an ever-increasing phenomenon. Energy production in a cleaner way is a global trend. For long, fossil fuels are responsible to meet the $80 \%$ of world energy demand [1]. But, the world is going to face a great problem 
with the energy crisis because of the depletion of fossil resources [2] [3]. Besides this, global warming due to greenhouse gas emission via burning fossils becomes the alarming concern of the international community [4]. As a result, the substitution of fossil fuels with sustainable and environmentally friendly energy sources is growing up with great interest. Fuels like $\mathrm{H}_{2}$ and biodiesel can be the alternative fuel from renewable sources [5] [6]. Low cost and environment benign processes or the preparation techniques of these promising fuels draw much attention to the researchers throughout the world. The process involves the selection of proper feed materials, good catalysts, optimum reaction conditions, etc. Here a suitable catalyst choice for effective fuel processing through thermo-catalytic reforming techniques or reactions from different hydrocarbons or biomass is must [7] [8]. Reaction conditions of these thermo-catalytic methods play a vital role in the final product. Catalyst is the most important controller or key to control the reaction conditions [9]-[13]. HT derived materials or mixed oxides are well established as catalysts because of their unique properties. Different factors are strongly related to the catalytic performance of HT derived materials. The performance of HT derived catalyst mostly depends on its preparation procedure [14] [15] [16] [17] [18], pore size [19], total surface area [20] [21] [22], modification [23] [24] [25] [26], types of metal constituents [18] [27] [28], composition [1] [29] [30] [31], promoters [32] [33] [34] [35], operating temperature [36]. Different metallic oxides prepared by HT precursors have shown super catalytic performance during fuel processing [5] [6] [14] [28] [36] [37] [38] [39] [40]. Sometimes, it is necessary to design or tune the HT derived catalyst for superior performance [41] [42]. This redesign can be done by being adjusted the $\mathrm{M}_{\mathrm{i}}$ and $\mathrm{M}_{\mathrm{ii}}$ metal ions as well as their ratio [41] [43] [44] [45] [46] [47]. Basąg et al., [18] reported that the performance of HT derived catalyst obtained at higher temperatures. In the last decades, a number of efforts have been taken where the focuses on highly stable and active catalysts. Catalyst deactivation through: 1) coke deposition, 2) sintering and 3) active site oxidation are the common phenomena that occurred during the thermochemical reaction to produce hydrogen or bio-fuel. These drawbacks are mostly removed by using various types of promoters, catalyst supports, and methods of preparation of catalysts. Ali Awad et al., [48] and Gennequin C. et al., [49] took a successful attempt to increase the lifetime of HT derived catalysts that showed longer deactivation time due to carbon deposition. The development of a bimetallic catalyst was one of the effective solutions to this of type of process [50]. Some scholars studied tri-metallic catalysts that exhibited outstanding performances over mono or bimetallic catalyst [51] [52] [53].

Hydrotalcite has a significant number of effective usages such as anion exchangers, polymer stabilizers, neutralizers (antacids), catalysts and catalyst supports, anion scavengers, electro-active, filtration, adsorbents, pharmaceutics and photoactive materials [54]-[60]. HT derived catalysts contain some unique properties over other materials due to its easier tunable properties, versatility, 
cost-effective materials, and simplicity. Hydrotalcite is considered a better precursor for developing user-friendly catalysts [61]. The catalysts obtained from HT precursors are widely used in fuel processing. Awad et al., observed $75 \%$ of $\mathrm{CH}_{4}$ conversion using $\mathrm{Ni}$ cased catalyst [48]. In spite of having superior performance ( $90 \%$ conversion yield) of Co-based catalysts, high cost, toxicity and the catalyst lifetime limit its application. Most of the cases $87 \%$ and $85 \%$ methane conversion were reported using tri-metallic $(10 \% \mathrm{Zn}-10 \% \mathrm{Cu}-50 \% \mathrm{Ni})$ catalysts at $1023^{\circ} \mathrm{K}$ temperature and bimetallic catalyst $(40 \% \mathrm{Coe} 10 \% \mathrm{~W})$ at $973^{\circ} \mathrm{K}$ respectively. Lower carbon deposition for tri-metallic catalysts was reported [62]. Reyna-villanueva et al., [53] obtained 98.59\% conversion of an ester using HT derived $\mathrm{Mg}$ - $\mathrm{Al}$ catalyst at $65^{\circ} \mathrm{C}$. The modification of $\mathrm{HT}$ derived catalyst is performing day by day to maximize its performance. The transesterification reactions are catalyzed by both heterogeneous and homogeneous catalysts, like alkoxides of various natures [63] [64] [65]. These catalysts can fasten the reaction remarkably. But some limitations like reactants purity, sensitive to fatty acid, toxicity and additional cost associated with purifying the final product decreases its applications [64] [66] [67]. Very recently, researchers are focusing on heterogeneous catalysts because of reusability, easy to recover, low purifying cost and simple process of final product separation, etc. [63] [68]. Li et al., [69] prepared HT derived Mg-Co-Al-La catalysts by co-precipitation method followed by calcination of $600^{\circ} \mathrm{C}$ for six hours. The application of $2 \%$ of this catalyst showed $96 \%$ - $97 \%$ product yields at $200^{\circ} \mathrm{C}$. Zeng et al., [70] found $90.5 \%$ ester conversion from $1.5 \% \mathrm{Mg} / \mathrm{Al}$ catalyst containing molar ratio 3 at $65^{\circ} \mathrm{C}$ for four hours while Liu et al., [19] achieved $93 \%$ conversion at $120^{\circ} \mathrm{C}$ for eight $(8)$ hours using $\mathrm{Mg} / \mathrm{Al}$ catalyst having molar ratio 2.3 but found no leaching. Sikander U. et al., [71] successfully tailored $\mathrm{Mg}-\mathrm{Ni}-\mathrm{Al}$ catalyst to understand the effect of $\mathrm{Ni}$ metal to produce hydrogen through thermal decomposition of $\mathrm{CH}_{4}$. They reported more than $80^{\circ} \%$ of methane conversion using $\mathrm{Mg}-\mathrm{Ni}-\mathrm{Al}$ catalyst doped $40 \% \mathrm{Ni}$ because of forming the spinel-like structure of carbon nanofiber formed during the course of a thermal decomposition reaction. Improved performance of HT derived catalysts in fuel processing was reported by various scholars [34] [72] [73].

Hydrotalcite derived materials have been investigated as catalyst widely for different reactions or processes. The phases or structure of the hydrotalcite derived catalyst, reaction or process conditions and its performances for hydrogen production is a vital factor for better applications or industrialization of the processes and further improvement. An updated collective summary for hydrogen production via reforming of methane/methanol/ethanol, their efficiency, catalytic conditions of those processes using hydrotalcite derived catalyst is rarely found [74]. This review highlights/finds the superior performance of the reforming or conversion reaction using hydrotalcite derived catalyst, catalytic conditions and how and why the catalyst performs best for hydrogen production. 


\section{Hydrotalcite Precursor to Final Fuel Processing Catalyst}

HT like materials is the best choice as a catalyst due to several properties like large surface area, memory effect, basicity, etc. [75] [76]. However, different techniques used to increase the catalytic activity and stability of HT before utilizing it in catalytic systems. Generally, the calcination treatment of HT was performed in air at a temperature ranging from $400^{\circ} \mathrm{C}$ to $800^{\circ} \mathrm{C}$ and time span between 4 and 6 hours [49] [77].

Impregnation of $\mathrm{HT}$ with promoter species was also found to enhance the performance of the HT catalyst very effectively. According to the literature reviewed here $\mathrm{HT}$ based catalysts impregnated with metal species like $\mathrm{Ni}, \mathrm{Ce}, \mathrm{Zr}$, Co, etc. exhibited higher activity, stability, and product yield during different fuel processing reactions [78] [79].

Other than calcination and metal impregnation, reduction pretreatment of HT in hydrogen and/or nitrogen environment at elevated temperatures (between $400^{\circ} \mathrm{C}$ and $800^{\circ} \mathrm{C}$ ) was also utilized by several researchers to achieve better performance from HT derived fuel processing catalysts [80].

\section{Hydrotalcite (HT) Based Catalysts for Hydrogen Production Reactions}

Hydrotalcite compound and its derivatives have been reported as active catalysts for various chemical processes like dry reforming of hydrocarbon, steam reforming of hydrocarbon, transesterification reaction, $\mathrm{NOX} \& \mathrm{CO}_{2}$ capture, etc. [81] [82] [83] [84]. Properties like large surface area, porosity, memory effect, small crystal size, thermal stability, and basic properties make HT and their derivatives are promising catalyst precursors for sustainable and eco-friendly fuel production. Results achieved by researchers reveal that catalysts derived from hydrotalcite precursors are potential candidates for application in industrial fuel processing systems [81] [82]. Effective utilization of mixed oxide catalyst synthesized from HT precursor for environmentally friendly fuel (hydrogen, alcohol, and bio-diesel) has been discussed below:

\subsection{HT Based Catalysts for $\mathrm{CO}_{2}$ or Dry Reforming of Methane (DRM)}

$\mathrm{CO}_{2}$ or dry reforming of methane (DRM) is an influential process for hydrogen $\left(\mathrm{H}_{2}\right)$ production and an effective way of the utilization of carbon dioxide $\left(\mathrm{CO}_{2}\right)$ and methane $\left(\mathrm{CH}_{4}\right)$ for environmentally friendly fuel production. DRM process has the potentiality of decreasing greenhouse gases like $\mathrm{CH}_{4}$ and $\mathrm{CO}_{2}$. The reaction for dry reforming of $\mathrm{CH}_{4}$ is given below [85]:

$$
\mathrm{CH}_{4}+\mathrm{CO}_{2} \rightarrow 2 \mathrm{CO}+2 \mathrm{H}_{2} ; \Delta \mathrm{H}=247.3 \mathrm{KJ} / \mathrm{mol}
$$

According to Equation (1): strong C-H $\left(439 \mathrm{kj} \cdot \mathrm{mol}^{-1}\right)$ bonds present in $\mathrm{CH}_{4}$ leads to an endothermic change in the DRM process that requires high temperature [86]. Researchers have investigated the DRM reaction mechanism, but some issues remained unsolved. For example, there are different views about 
rate-determining steps (RDS) [87] [88]. DRM process is mainly affected by temperature, activity, $\mathrm{H}_{2} / \mathrm{CO}$ ratio and carbon deposition [89]. Where higher temperatures ensure better productivity but make the DRM method less feasible for industrial applications. The introduction of the catalyst has the potentiality to solve the problem as catalysts make higher activities achievable at lower temperatures. For $50 \% \mathrm{CO}_{2}$ conversion in the DMR process temperature as high as $1035^{\circ} \mathrm{C}$ is needed if no catalyst was used [89]. According to recent literature reviews and experiments where catalysts used, especially hydrotalcite based catalysts ensure higher $\mathrm{CO}_{2}$ and $\mathrm{CH}_{4}$ conversions at temperatures lower than $800^{\circ} \mathrm{C}$. It is investigated that, methane can be activated and absorbed by the active sites of transition metals present in group 9 and 10 of the periodic table, while Carbon dioxide can be activated and absorbed by oxides [90]. This makes transition metal promoted hydrotalcite derived catalysts promising for the DRM process. Table 1 presents recent works by different researchers on hydrotalcite derived catalysts for DRM.

Accordingly, Oscar et al., [91] synthesized Pr promoted Ni-Mg-Al based hydrotalcite catalyst by the self-combustion method with microwave-assistance. They found that the promotion of Praseodymium (Pr) in Ni-Mg-Al improved catalyst stability and reduced the carbon deposits on the catalyst surface. However, the incorporation of $\operatorname{Pr}$ did not increase the performance of the developed catalyst. Then again, Tanios et al., synthesized $\mathrm{Co}, \mathrm{Ni}, \mathrm{Mg}$, and Al-based catalyst by hydrotalcite route. The synthesized $\mathrm{Co}_{2} \mathrm{Ni}_{2} \mathrm{Mg}_{2} \mathrm{Al}_{2} 800$ catalyst showed better conversions than commercial $\mathrm{Ni}(50 \%) / \mathrm{Al}_{2} \mathrm{O}_{3}$ catalyst. The difference in catalytic performance between $\mathrm{Co}_{2} \mathrm{Ni}_{2} \mathrm{Mg}_{2} \mathrm{Al}_{2} 800$ and commercial $\mathrm{Ni}(50 \%) / \mathrm{Al}_{2} \mathrm{O}_{3}$ catalyst was higher in temperatures $500{ }^{\circ} \mathrm{C}$ and $700^{\circ} \mathrm{C}$. The developed catalyst contained less $\mathrm{Ni}$ than the commercial catalyst. Moreover, the new catalyst showed good stability at $800^{\circ} \mathrm{C}$. Pellet and powder form of the catalyst showed similar methane conversions. The researchers also found that the presence of toluene decreases $\mathrm{CH}_{4}$ conversion by an average of $15 \%$. Meanwhile, $\mathrm{CO}_{2}$ conversion remains almost unaffected by toluene. On the other hand, cerium (Ce) and yttrium (Y) promoted double layered hydroxide (hydrotalcite) catalyst was synthesized by Swirk et al. [92] to study the effect of Y on DRM. They promoted hydrotalcite (containing $\mathrm{Ni}^{2+}, \mathrm{Mg}^{2+} \& \mathrm{Al}^{3+}$ ions) with Ce by co-precipitation method and promoted hydrotalcite with $\mathrm{Y}$ by impregnation method. Their study revealed that incorporation of $\mathrm{Y}$ and Ce decreased $\mathrm{Ni}$ reducibility, improved Ni dispersion, reduced $\mathrm{Ni}$ crystal size and increased basicity. Ce Promotion increased both $\mathrm{CH}_{4}$ and $\mathrm{CO}_{2}$ conversions at the temperature range of $600^{\circ} \mathrm{C}-750^{\circ} \mathrm{C}$ and 0.2 $\mathrm{wt} \%$ loading of yttrium increased conversions during isothermal DRM tests. Elsewhere, the catalytic performance of layered double hydroxide (hydrotalcite) containing a certain amount of $\mathrm{Ni}$ and promoted with Iron ( $\mathrm{Fe}$ ) was evaluated by Wierzbicki et al., [93] for the DRM process. The tests revealed that, a small amount of $\mathrm{Fe}$ incorporation affected $\mathrm{CO}_{2}$ adsorption, increased moderate basic sites and at a low temperature of $250^{\circ} \mathrm{C}$ increased catalytic activity. However, decreased catalytic performance was observed during higher Fe promotions. 
Table 1. Review report of HT based catalyst for $\mathrm{CO}_{2}$ or Dry Reforming of Methane (DRM).

\begin{tabular}{|c|c|c|c|c|c|c|}
\hline \multirow{2}{*}{ Catalyst Applied } & \multirow{2}{*}{ Method of synthesis } & \multirow{2}{*}{$\begin{array}{l}\text { Test } \\
\text { Conditions }\end{array}$} & \multicolumn{2}{|l|}{ Observations } & \multirow{2}{*}{$\begin{array}{l}\mathrm{CH}_{4} \\
\text { Conversion \% }\end{array}$} & \multirow{2}{*}{ Ref. } \\
\hline & & & Achievement & Limitation & & \\
\hline $\begin{array}{l}\text { Pr promoted } \\
\mathrm{Ni}-\mathrm{Mg}-\mathrm{Al}\end{array}$ & $\begin{array}{l}\text { Microwave-assisted } \\
\text { self-combustion method }\end{array}$ & $\begin{array}{l}600^{\circ} \mathrm{C} \& \\
\text { atmospheric } \\
\text { pressure }\end{array}$ & $\begin{array}{l}6 \mathrm{wt} \% \text { of } \operatorname{Pr} \text { decreased the } \\
\text { formation of carbon deposits } \\
\text { and improved the catalytic } \\
\text { stability }\end{array}$ & \multicolumn{2}{|c|}{$\begin{array}{l}\text { Pr only increased the thermal } \\
\text { stability but did not improve } 58 \\
\text { catalytic conversion }\end{array}$} & {$[91]$} \\
\hline $\mathrm{Co}_{2} \mathrm{Ni}_{2} \mathrm{Mg}_{2} \mathrm{Al}_{2}$ & $\begin{array}{l}\text { Co-precipitation, Grinding } \\
\text { and finally calcination at } \\
800^{\circ} \mathrm{C} \text { for } 4 \mathrm{~h}\end{array}$ & $\begin{array}{l}400^{\circ} \mathrm{C} \text { to } \\
800^{\circ} \mathrm{C}\end{array}$ & $\begin{array}{l}\text { More active and more stable } \\
\text { (less deactivated by } \\
\text { carbon) than commercial } \\
\mathrm{Ni}(50 \%) / \mathrm{Al}_{2} \mathrm{O}_{3} \text { catalyst }\end{array}$ & $\begin{array}{l}\text { Presence of toluene } \\
\text { decreased the methane } \\
\text { conversion }\end{array}$ & 97 & {$[49]$} \\
\hline $\begin{array}{l}\mathrm{Ce} \text { - and } \\
\text { Y-promoted Htlc } \\
\text { of } \mathrm{Ni}_{2+}, \mathrm{Mg}_{2+} \\
\mathrm{Al}_{3+} \text { and/or } \mathrm{Ce}_{3+}\end{array}$ & $\begin{array}{l}\text { Co-precipitation followed by } \\
\mathrm{Y} \text { impregnation and then } \\
\text { calcination at } 550^{\circ} \mathrm{C} \text { for } 5 \mathrm{~h}\end{array}$ & $\begin{array}{l}\text { Range of } \\
850^{\circ} \mathrm{C}-600^{\circ} \mathrm{C} \\
\text { and isothermal } \\
\text { test at } 700^{\circ} \mathrm{C}\end{array}$ & $\begin{array}{l}\text { Promotion of Ce increased } \\
\text { both } \mathrm{CO}_{2} \text { and } \mathrm{CH}_{4} \\
\text { conversions at the temperature } \\
\text { range of } 600^{\circ} \mathrm{C}-750^{\circ} \mathrm{C} \text { and } \\
0.2 \mathrm{wt} \% \text { loading of yttrium } \\
\text { increased both } \mathrm{CO}_{2} \text { and } \mathrm{CH}_{4} \\
\text { conversions during } \\
\text { isothermal DRM tests }\end{array}$ & $\begin{array}{l}\text { Catalyst promoted with Ce } \\
\text { and } 0.6 \text { wt } \% \text { of } Y \text { showed } \\
\text { decreased catalytic } \\
\text { performance and highest } \\
\text { basicity. }\end{array}$ & 96.2 & {$[92]$} \\
\hline $\begin{array}{l}\mathrm{Ni} \& \mathrm{Fe} \\
\text { promoted Htlc } \\
\text { of } \mathrm{Al} \& \mathrm{Mg}\end{array}$ & $\begin{array}{l}\text { Co-precipitation followed by } \\
\text { calcination at } 500^{\circ} \mathrm{C} \text { for } 5 \mathrm{~h}\end{array}$ & $250^{\circ} \mathrm{C}$ & $\begin{array}{l}\text { Low amount of } \mathrm{Fe} \text { activated } \\
\text { the catalysts at low } \\
\text { temperature }\left(250^{\circ} \mathrm{C}\right)\end{array}$ & $\begin{array}{l}\text { incorporation of higher } \\
\text { amounts of Fe decreased } \\
\text { catalytic activity }\end{array}$ & 99 & {$[93]$} \\
\hline $\begin{array}{l}\text { Co supported } \\
\mathrm{Mg}-\mathrm{Al}\end{array}$ & $\begin{array}{l}\text { Co-precipitation and then } \\
\text { calcination for } 4 \mathrm{~h} \text { at } \\
600^{\circ} \mathrm{C}\end{array}$ & $\begin{array}{l}700^{\circ} \mathrm{C} \& \\
\text { ambient } \\
\text { pressure }\end{array}$ & $\begin{array}{l}\text { Fantastic initial activity, } \\
\text { significant long term stability, } \\
\text { improvement in coke and } \\
\text { sintering resistance }\end{array}$ & $\begin{array}{l}\mathrm{CH}_{4} \text { conversion is below } \\
60 \%\end{array}$ & 58.6 & {$[95]$} \\
\hline $\mathrm{Co} / \mathrm{Mg}(\mathrm{Al}) \mathrm{O}$ & $\begin{array}{l}\text { Co-precipitation, then } \\
\text { calcination and reduction } \\
\text { for } 5 \text { hat } 800^{\circ} \mathrm{C}\end{array}$ & $500^{\circ} \mathrm{C}-750^{\circ} \mathrm{C}$ & $\begin{array}{l}\mathrm{Co} / \mathrm{Mg}(\mathrm{Al}) \mathrm{O}-\mathrm{Htlc} \text { catalyst was } \\
\text { found promising for } \mathrm{CH}_{4} \\
\text { reforming at low-temperature }\end{array}$ & $\begin{array}{l}\text { s At higher temperature } \\
\left(\sim 750^{\circ} \mathrm{C}\right) \text { Co catalyst was } \\
\text { inferior to Ni catalyst }\end{array}$ & 86.7 & {$[96]$} \\
\hline $\begin{array}{l}\mathrm{CeO}_{2}, \mathrm{ZrO}_{2} \& \mathrm{ZnO} \\
\text { promoted } \\
\mathrm{NiO} / \mathrm{Mg}(\mathrm{Al}) \mathrm{O}\end{array}$ & $\begin{array}{l}\text { Co-precipitation and then } \\
\text { calcination at } 600^{\circ} \mathrm{C} \text { in air } \\
\text { for } 6 \mathrm{~h}\end{array}$ & $750^{\circ} \mathrm{C}$ & $\begin{array}{l}\text { The work presented kinetic } \\
\text { and mechanistic insights into } \\
\text { the functions of Ni-Htlc } \\
\text { catalysts in DRM }\end{array}$ & $\begin{array}{l}\text { The developed oxide } \\
\text { promoted catalysts exhibited } \\
\text { slightly lower activity than } \mathrm{N} \\
\text { catalyst }\end{array}$ & ii $75-80$ & {$[97]$} \\
\hline $\begin{array}{l}\text { Y promoted } \mathrm{Ni} \\
\text { containing } \mathrm{Mg} / \mathrm{Al}\end{array}$ & $\begin{array}{l}\text { Co-precipitation and then } \\
\text { calcination at } 550^{\circ} \mathrm{C} \text { in air } \\
\text { for } 5 \mathrm{~h}\end{array}$ & $600^{\circ} \mathrm{C}-850^{\circ} \mathrm{C}$ & $\begin{array}{l}\text { Y (yttrium) promotion raised } \\
\text { the fraction of medium basic } \\
\text { sites, reduced Ni crystallite } \\
\text { size, and increased specific } \\
\text { surface area }\end{array}$ & $\begin{array}{l}\text { The total basicity of catalyst } \\
\text { decreased due to Y (yttrium) } \\
\text { promotion }\end{array}$ & 88 & {$[98]$} \\
\hline $\begin{array}{l}\mathrm{CoAl} \text { and } \\
\mathrm{CoFeHtlc}\end{array}$ & $\begin{array}{l}\text { Co-precipitation followed } \\
\text { by calcination at } 800^{\circ} \mathrm{C} \text { in } \\
\text { an oven for } 6 \mathrm{~h}\end{array}$ & $\begin{array}{l}\text { Between } \\
400^{\circ} \mathrm{C}-700^{\circ} \mathrm{C} \\
\text { \& atmospheric } \\
\text { pressure }\end{array}$ & $\begin{array}{l}\text { CoAl-Htlc catalyst showed } \\
\text { better stability and higher } \\
\text { catalytic activity during the } \\
\text { DRM reaction compared to } \\
\text { Co Fe-Htlc catalyst }\end{array}$ & $\begin{array}{l}\text { Fe based catalyst exhibited } \\
\text { lower reactivity due to the } \\
\text { active phase re-oxidation by } \\
\text { the water formed during } \\
\text { reverse WGS reaction }\end{array}$ & $66.4 \& 54.5$ & [99] \\
\hline $\begin{array}{l}\mathrm{Zr} \text { - and } \\
\text { Y-promoted } \\
\mathrm{Ni} / \mathrm{Mg} / \mathrm{Al}-\mathrm{Htlc}\end{array}$ & $\begin{array}{l}\text { Co-precipitation and then } \\
\text { calcination at } 550^{\circ} \mathrm{C} \text { in air } \\
\text { for } 5 \mathrm{~h}\end{array}$ & $\begin{array}{l}600^{\circ} \mathrm{C}-850^{\circ} \mathrm{C} \\
\text { with a } \\
\text { temperature } \\
\text { step of } 50^{\circ} \mathrm{C}\end{array}$ & $\begin{array}{l}\text { Strong interaction between } \\
\text { nickel and the promoted Htlc } \\
\text { support with low } \mathrm{H}_{2} \\
\text { consumption was reported }\end{array}$ & Reducibility decreased & 72.7 & {$[100]$} \\
\hline $\mathrm{Ni}-\mathrm{Mg}-\mathrm{Al}$ & $\begin{array}{l}\text { Co-precipitation \& incipient } \\
\text { wetness impregnation }\end{array}$ & $750^{\circ} \mathrm{C}$ & $\begin{array}{l}\text { Good stability against } \\
\text { sintering and coking with } \\
\text { improved activity was } \\
\text { observed during DRM process } \\
\text { having industrially relevant } \\
\text { reaction conditions }\end{array}$ & $\begin{array}{l}\text { During DRM carbon } \\
\text { deposition in the catalyst } \\
\text { increased at lower } \\
\text { temperatures }\end{array}$ & 53.6 & {$[101]$} \\
\hline
\end{tabular}




\section{Continued}

\begin{tabular}{|c|c|c|c|c|c|c|}
\hline $\begin{array}{l}\mathrm{Ni}_{\mathrm{x}} \mathrm{Mg}_{6-\mathrm{x}} \\
\mathrm{Al}_{1.8} \mathrm{La}_{0.2}\end{array}$ & $\begin{array}{l}\text { Co-precipitation and calcined } \\
\text { under an airflow at } 800^{\circ} \mathrm{C}\end{array}$ & $600^{\circ} \mathrm{C}-800^{\circ} \mathrm{C}$ & $\begin{array}{l}\text { Catalyst exhibited increased } \\
\mathrm{CH}_{4} \text { and } \mathrm{CO}_{2} \text { conversion } \\
\text { thenLa free catalyst }\end{array}$ & $\begin{array}{l}\text { carbon deposition on the } \\
\text { catalyst surface was } \\
\text { Significant }\end{array}$ & $75-80$ & [102] \\
\hline $\begin{array}{l}\text { La promoted } \\
\mathrm{Ni}-\mathrm{Mg}-\mathrm{Al}\end{array}$ & $\begin{array}{l}\text { Co-precipitation followed } \\
\text { by calcination at } 600^{\circ} \mathrm{C} \text { for } 6 \\
\text { hours in flowing air }\end{array}$ & $600^{\circ} \mathrm{C} \& 750^{\circ} \mathrm{C}$ & $\begin{array}{l}\text { La-promotion enhanced the } \\
\text { reducibility of } \mathrm{NiO} \text { and was } \\
\text { Cbeneficial for preparing } \\
\text { hydrotalcite based Ni catalysts } \\
\text { for DRM }\end{array}$ & $\begin{array}{l}\text { deactivation of the catalyst is } \\
\text { severe at low temperatures }\end{array}$ & 82 & [103] \\
\hline $\begin{array}{l}\text { Ce promotion } \\
\mathrm{Ni} / \mathrm{Al} \text { and } \\
\mathrm{Ni} / \mathrm{Mg} / \mathrm{Al}\end{array}$ & $\begin{array}{l}\text { Co-precipitation, calcination } \\
\text { in the stream of air for } 4 \mathrm{~h} \\
\text { at } 550^{\circ} \mathrm{C} \text { and then adsorption } \\
\text { of } \mathrm{Ce}\end{array}$ & $\begin{array}{l}550^{\circ} \mathrm{C}, 650^{\circ} \mathrm{C} \\
\& 750^{\circ} \mathrm{C}\end{array}$ & $\begin{array}{l}\text { Ce-promotion in } \mathrm{Ni} / \mathrm{Mg} / \mathrm{Al} \\
\text { and } \mathrm{Ni} / \mathrm{Al} \text { increased } \mathrm{CH}_{4} \\
\text { concentrations and affected } \\
\text { both activity, selectivity and } \\
\text { stability of the developed } \\
\text { catalyst }\end{array}$ & $\begin{array}{l}\text { Excess presence of } \mathrm{CH}_{4} \text { and } \\
\mathrm{CO}_{2} \text { in the feed decreases } \\
\text { both } \mathrm{CH}_{4} \text { and } \mathrm{CO}_{2} \\
\text { conversions }\end{array}$ & 87 & [104] \\
\hline $\begin{array}{l}\text { Zr promoted } \\
\mathrm{Mg}(\mathrm{Ni}, \mathrm{Al}) \mathrm{O}\end{array}$ & $\begin{array}{l}\text { Co-precipitation followed } \\
\text { by calcination at } 550^{\circ} \mathrm{C} \text { for } \\
4 \mathrm{~h}\end{array}$ & $\begin{array}{l}550^{\circ} \mathrm{C}, 650^{\circ} \mathrm{C} \\
\& 750^{\circ} \mathrm{C}\end{array}$ & $\begin{array}{l}\text { The amount of incorporated } \\
\mathrm{Zr} \text { and its placement in the } \\
\text { catalyst system affected } \\
\text { activity, basicity, and textural } \\
\text { properties of the catalyst }\end{array}$ & $\begin{array}{l}\text { Zr introduction to the } \\
\text { catalyst system decreased } \\
\text { activity. }\end{array}$ & 83 & [105] \\
\hline $\begin{array}{l}\mathrm{Ni} \text { containing } \\
\mathrm{Mg}-\mathrm{Al}\end{array}$ & $\begin{array}{l}\text { Co-precipitation and then } \\
\text { calcination for } 5 \mathrm{~h} \text { at } 500^{\circ} \mathrm{C}\end{array}$ & $300^{\circ} \mathrm{C}$ & $\begin{array}{l}\text { Higher } \mathrm{Ni} \text { incorporation } \\
\text { affected both the } \mathrm{CO}_{2} \\
\text { adsorption capacity andthe } \\
\text { reducibility of the catalysts }\end{array}$ & $\begin{array}{l}\mathrm{CH}_{4} \text { selectivity of the } \\
\text { catalyst decreases at higher } \\
\text { temperatures } \\
\left(400^{\circ} \mathrm{C}-450^{\circ} \mathrm{C}\right)\end{array}$ & 98.3 & [106] \\
\hline $\mathrm{NiMgAl}$ & $\begin{array}{l}\text { Co-precipitation followed } \\
\text { by calcination in the static } \\
\text { air at } 500^{\circ} \mathrm{Cf} \text { or } 10 \mathrm{~h}\end{array}$ & $800^{\circ} \mathrm{C}$ & $\begin{array}{l}\text { Catalysts with a higher } \mathrm{Mg} / \mathrm{Al} \\
\text { ratio exhibited better } \\
\text { resistance to coke formation } \\
\text { and catalytic activity. } \\
\mathrm{Ni}-\mathrm{Mg}-\mathrm{Al} \text { catalyst with } \mathrm{Mg} / \mathrm{Al} \\
\text { ratio of } 1 \text { exhibited the best } \\
\text { catalytic performance and } \\
\text { stability }\end{array}$ & $\begin{array}{l}\text { Low activity and stability } \\
\text { was reported for Al-rich } \\
\text { catalysts }\end{array}$ & 83 & [107] \\
\hline $\mathrm{Ni}-\mathrm{Mg}-\mathrm{Al}$ & $\begin{array}{l}\text { Co-precipitation followed } \\
\text { by calcination for } 6 \mathrm{hrs} \text { at } \\
\text { different temperatures of } \\
300^{\circ} \mathrm{C}, 400^{\circ} \mathrm{C}, 500^{\circ} \mathrm{C} \text {, } \\
600^{\circ} \mathrm{C}, 700^{\circ} \mathrm{C} \text {, and } 800^{\circ} \mathrm{C}\end{array}$ & $\begin{array}{l}\text { Temperatures } \\
\text { between } \\
400^{\circ} \mathrm{C} \text { and } \\
700^{\circ} \mathrm{C} \& \\
\text { atmospheric } \\
\text { pressure }\end{array}$ & $\begin{array}{l}\text { High catalytic performance } \\
\text { due to the lower size of nickel } \\
\text { and better stability of the Htlc } \\
\left(\mathrm{NiAl}_{2} \mathrm{O}_{4}\right) \text { support }\end{array}$ & $\begin{array}{l}\text { Reduction temperature } \\
\text { increases with increasing } \\
\text { calcination temperatures }\end{array}$ & 90 & [108] \\
\hline $\begin{array}{l}\mathrm{CeZr}, \mathrm{Zr} \text {, and } \mathrm{Ce} \\
\text { promoted } \\
\mathrm{Ni}-\mathrm{Mg}-\mathrm{Al}\end{array}$ & $\begin{array}{l}\text { Co-precipitation and then } \\
\text { calcination for } 4 \mathrm{~h} \text { at } \\
550^{\circ} \mathrm{C}\end{array}$ & $550^{\circ} \mathrm{C}$ & $\begin{array}{l}\mathrm{Zr} \text { affected both the selectivity } \\
\text { and catalytic activity of the } \\
\text { catalyst }\end{array}$ & $\begin{array}{l}\text { Conversion of both } \mathrm{CO}_{2} \\
\text { and } \mathrm{CH}_{4} \text { was comparatively } \\
\text { low }\end{array}$ & 40 & [78] \\
\hline $\begin{array}{l}\mathrm{CeO}_{2} \text {-modified } \\
\mathrm{Ni}-\mathrm{Mg} \text { - } \mathrm{Al}\end{array}$ & $\begin{array}{l}\text { Co-precipitation and then } \\
\text { calcination for } 4 \mathrm{~h} \text { at } \\
650^{\circ} \mathrm{C}\end{array}$ & $\begin{array}{l}0.1 \mathrm{MPa} \& \\
750^{\circ} \mathrm{C}\end{array}$ & $\begin{array}{l}\mathrm{CeO}_{2} \text {-modified catalysts } \\
\text { presented high activity during } \\
\text { pressurized DRM }\end{array}$ & $\begin{array}{l}\mathrm{CeO}_{2} \text { addition by both } \\
\text { co-precipitation and } \\
\text { impregnation method led } \\
\text { to a decrease in the pore } \\
\text { diameter, total pore volume, } \\
\text { and surface area. }\end{array}$ & 58 & [109] \\
\hline $\mathrm{Ni}-\mathrm{Mg}-\mathrm{Al}$ & $\begin{array}{l}\text { Co-precipitation followed by } \\
\text { calcination at } 800^{\circ} \mathrm{C} \text { for } 5 \mathrm{~h} \text {. }\end{array}$ & $400^{\circ} \mathrm{C}$ to $800^{\circ} \mathrm{C}$ & $\begin{array}{l}\text { Catalysts exhibited increased } \\
\text { activity for both the } \mathrm{CH}_{4} \text { and } \\
\mathrm{CCO}_{2} \text { reforming. Moreover, } \\
\text { increasing Ni loadings } \\
\text { promoted activity }\end{array}$ & $\begin{array}{l}\text { At low temperature }\left(600^{\circ} \mathrm{C}\right) \\
\text { catalytic stability decreased } \\
\text { with higher Ni loadings }\end{array}$ & 86 & [110] \\
\hline
\end{tabular}


The catalytic activity of cobalt $(\mathrm{Co})$ supported hydrotalcite $(\mathrm{Mg}, \mathrm{Al})$ catalyst on DRM was studied by Guo et al., [94]. They synthesized Co/MgAl catalyst having a hydrotalcite-like structure of MgAl. The developed catalyst has a significant amount of medium basic sites, impressive initial activity, comparatively higher stability and better resistance to sintering and cooks formation. Co supported hydrotalcite catalyst $\mathrm{Co} / \mathrm{Mg}_{3} \mathrm{Al}$ was also studied by Li et al., [95] to investigate its performance on low-temperature DRM. They also compared the performance of $\mathrm{Co} / \mathrm{Mg}_{3} \mathrm{Al}$ with nickel-based catalyst $\mathrm{Ni} / \mathrm{Mg}_{3} \mathrm{Al}$. According to their comparative study revealed $\mathrm{Co} / \mathrm{Mg}_{3} \mathrm{Al}$ demonstrated better catalytic activity than $\mathrm{Ni} / \mathrm{Mg}_{3} \mathrm{Al}$ at low temperate. Co catalysts showed high cook resistance and stable catalytic activity at both low and high temperatures. Hydrotalcite based nickel (Ni) catalyst containing little amount of $\mathrm{CeO}_{2}, \mathrm{ZrO}_{2}$ and $\mathrm{ZnO}$ oxides as promoters have been studied by Niu et al., [96]. According to their study $\mathrm{CeO}_{2}-\mathrm{Ni}-\mathrm{Hydrotalcite} \mathrm{has} \mathrm{bet-}$ ter stability, highest $\mathrm{H}_{2} / \mathrm{CO}_{2}$ ratio and $\mathrm{CO}_{2}$ activation among the developed catalysts. They also observed that oxide promotion slightly decreased the performance of the Ni-catalyst. Then again, Świrk et al., [97] promoted Ni-based hydrotalcite catalyst with yttrium (Y). The addition of $1.5 \mathrm{wt} \%$ of $\mathrm{Y}$ increased the catalytic performance of the Ni-(Mg/Al) hydrotalcite catalyst. They also reported increased specific surface area, a higher fraction of medium basic sites and reduced $\mathrm{Ni}$ crystallite size. Aider et al., [98] developed Co-Al-hydrotalcite and Co-Fehydrotalcite catalysts to enhance the catalyst stability and resistance to carbon deposition during the DRM process. Their study revealed that, Co-Al-hydrotalcite has higher catalytic activity due to higher specific surface area, the smaller size of Co and presence of homogeneous Co particles, but due to the active phase re-oxidation of by water, Co-Fe-hydrotalcite has an inferior catalytic performance. Świrk et al., [99] studied DRM over Zr (zirconium) and (Y) yttrium promoted hydrotalcite $(\mathrm{Ni} / \mathrm{Mg} / \mathrm{Al})$ catalyst. The $\mathrm{Zr}$ and $\mathrm{Y}$ impregnated Ni/Mg/Al-HT improved catalytic activity and the modified catalyst was stable in DRM at $700^{\circ} \mathrm{C}$. Kalai et al., [100] developed $\mathrm{Ni}(\mathrm{Mg})-\mathrm{Al} \mathrm{Htlc}$ catalyst by conventional incipient wetness impregnation method for Ni promotion and co-precipitation method for hydrotalcite development. Their synthesized $20 \mathrm{Ni}-\mathrm{Mg}$ - $\mathrm{Al}$ catalyst exhibited high $\mathrm{CH}_{4}$ conversion and a low deactivation rate during DRM. The stability of the developed catalyst was also remarkable.

Dahdah et al., [101] experimented on the effect of lanthanum (La) doping on hydrotalcite $\left(\mathrm{Ni}_{x} \mathrm{Mg}_{6-\mathrm{x}} \mathrm{Al}_{2}\right)$ catalyst for $\mathrm{CO}_{2}$ reforming of methane. $\mathrm{Ni}_{2} \mathrm{Mg}_{4} \mathrm{Al}_{1.8} \mathrm{La}_{0.2}$ catalyst synthesized by Dahdah and co-workers [101] exhibited better catalytic performance by means of $\mathrm{CH}_{4}$ and $\mathrm{CO}_{2}$ conversions, increment of basic sites and catalyst stability. They also mentioned that La helped to remove deactivating carbon by forming $\mathrm{La}_{2} \mathrm{O}_{2} \mathrm{CO}_{3}$. Kalai et al., [102] also evaluated La promotion on hydrotalcite derived Ni catalyst for DRM. They concluded that La promotion is beneficial to develop hydrotalcite derived Ni catalyst for DRM. They also mentioned about the formation of lanthanum carbonate hydroxide phase due to La addition. Debek et al., [103], examined the performance of hydrotalcite (Ni/Mg/Al 
and $\mathrm{Ni} / \mathrm{Al}$ ) derived catalyst promoted with cerium (Ce) on DRM. They promoted hydrotalcite precursor $\mathrm{Ni} / \mathrm{Mg} / \mathrm{Al}$ and $\mathrm{Ni} / \mathrm{Al}$ with $\mathrm{Ce}$ by adsorption of $\mathrm{Ce}$ species from $[\mathrm{Ce}(\mathrm{EDTA})]^{-}$solution. The Ce promoted catalyst found to increase $\mathrm{CH}_{4}$ conversion in DRM, but an increased amount of $\mathrm{CH}_{4}$ and $\mathrm{CO}_{2}$ in the feed adversely affected both $\mathrm{CH}_{4}$ and $\mathrm{CO}_{2}$ conversions. In another study Debek et al., [104] evaluated zirconia promoted $\mathrm{Mg}(\mathrm{Ni}, \mathrm{Al}) \mathrm{O}$ Htlcs catalyst in $\mathrm{CO}_{2}$ reforming of $\mathrm{CH}_{4}$. Here, $\mathrm{Zr}$ species was introduced at the co-precipitation stage. Their investigative study revealed that the introduction of $\mathrm{Zr}$ strongly enhanced selectivity and stability of the catalyst, but reduced activity. Ni containing hydrotalcite (Mg-Al) catalyst was studied by Wierzbicki et al., [105]. According to the researchers, the presence of $\mathrm{Ni}$ increased the reducibility and $\mathrm{CO}_{2}$ adsorption capacity of the catalyst.

Zhu et al., [106] examined the effect of $\mathrm{Mg} / \mathrm{Al}$ ratio in Ni-Mg-Al hydrotalcite catalyst during DRM. They found that a higher ratio of $\mathrm{Mg}$ and $\mathrm{Al}$ in the catalyst leads to higher activity and stability. Where 1 is found to be the best ratio between $\mathrm{Mg}$ and $\mathrm{Al}$. Then again, the effect of $\mathrm{Ni} / \mathrm{Al}$ ratio in the hydrotalcite catalyst for DRM was studied by F. Touahra and co-workers [107]. According to their study, catalytic activity of the $\mathrm{Ni}-\mathrm{Mg} / \mathrm{Al}$ hydrotalcite catalyst was proportional to the molar ratio of $\mathrm{Ni}^{2+} / \mathrm{Al}^{3+}$ in the catalyst and higher calcination temperature during catalyst synthesis was found to enhance activity. Ce- $\mathrm{Zr}, \mathrm{Zr}$, and Ce promoted Ni-Mg-Al (hydrotalcite) catalysts were synthesized by Debek et al., to evaluate its performance over low-temperature dry methane reforming. They reported reduced conversion of both $\mathrm{CH}_{4}$ and $\mathrm{CO}_{2}$ but the incorporation of $\mathrm{Zr}$ in the developed catalyst helped to determine both selectivity and activity of the catalyst. Likewise, $\mathrm{CeO}_{2}$ to promote hydrotalcite $(\mathrm{Ni}-\mathrm{Mg} / \mathrm{Al})$ catalyst for pressurized $\mathrm{CO}_{2}$ reforming of $\mathrm{CH}_{4}$ was studied by Ren and co-workers [108]. Both the impregnation and co-precipitation method was utilized by the researchers to add $\mathrm{CeO}_{2}$ in the Ni-Mg-Al precursor. $\mathrm{CeO}_{2}$ incorporation increased activity but decreased stability and surface area of the catalyst. Finally, the influence of $\mathrm{Ni}$ loading on $\mathrm{Ni}-\mathrm{Mg} / \mathrm{Al}$ hydrotalcite catalysts for $\mathrm{CO}_{2}$ reforming of $\mathrm{CH}_{4}$ was studied by Lin et al., [109]. According to their work hydrotalcite derived Ni/Mg-Al catalysts were mentioned to be highly active for $\mathrm{CO}_{2}$ reforming of $\mathrm{CH}_{4}$. They also observed that at higher temperatures sintering of $\mathrm{Ni}$ particles increases and coke deposition decreases with higher Ni loadings in the catalyst.

$\mathrm{Mg}(\mathrm{Al}) \mathrm{O}$ hydrotalcite type catalysts are promising for $\mathrm{CO}_{2}$ reforming of $\mathrm{CH}_{4}(\mathrm{DRM})$. Especially, Ni-based hydrotalcite (Ni-Mg-Al) material promoted with metals like $\mathrm{Zr}, \mathrm{Y}, \mathrm{Ce}, \mathrm{Co}$, and $\mathrm{Pr}$ showed potential development in catalytic properties during DRM such as improved activity, stability, coke resistance, and sintering resistance.

\subsection{HT Based Catalysts for Steam Reforming of Methane (SRM)}

Steam reforming of methane (SRM) or wet reforming of $\mathrm{CH}_{4}$ is a well-established and industrially applied process for $\mathrm{H}_{2}$ production. Generally, methane is used 
for hydrogen production in steam reforming technology but other light hydrocarbons can also be used. In this process, hydrogen $\left(\mathrm{H}_{2}\right)$ and carbon monoxide (CO) is produced by reacting methane $\left(\mathrm{CH}_{4}\right)$ and steam $\left(\mathrm{H}_{2} \mathrm{O}\right)$. $\mathrm{CO}$ generation in the reaction is subjected to the WGS (water gas shift) reaction to increasing hydrogen productivity. Equation (2) and (3) illustrates the reactions for the process.

$$
\begin{aligned}
& \mathrm{CH}_{4}+\mathrm{H}_{2} \mathrm{O} \rightarrow \mathrm{H}_{2}+\mathrm{CO} ; \Delta \mathrm{H}=206 \mathrm{KJ} / \mathrm{mol} \\
& \mathrm{CO}+\mathrm{H}_{2} \mathrm{O} \rightarrow \mathrm{H}_{2}+\mathrm{CO}_{2} ; \Delta \mathrm{H}=-41 \mathrm{KJ} / \mathrm{mol}
\end{aligned}
$$

The temperature of the reactions is usually above $700^{\circ} \mathrm{C}$ and the catalyst is used to enhance $\mathrm{H}_{2}$ yield. Nickel (Ni) based catalyst is generally used in SRM for their cost-effectiveness and availability. However, $\mathrm{Ni}$ as a compound is less activated than other metals and during SRM Ni catalysts become deactivated due to sintering of active phase and coke formation in the surface [110]. Catalytic supports are very effective in reducing coke deposition and sintering [111]. Hydrotalcite catalyst has a large surface area, uniform active metal distribution on the surface and basicity which makes hydrotalcite based catalyst very promising for SRM [112]. This is why hydrotalcite based catalysts are potential for SRM. Hydrotalcite catalysts promoted with metals like $\mathrm{Ni}, \mathrm{Ce}, \mathrm{Zr}, \mathrm{Rh}$, etc. are studied for SRM by researchers and promising results were found. The recent development of hydrotalcite based catalyst for SRM is presented in Table 2.

Fasolini et al., synthesized Rh-Mg-Al hydrotalcite catalyst for SRM and they found that a lower $\mathrm{Mg} / \mathrm{Al}$ ratio and higher rhodium (Rh) amount (from $1 \%$ to $2 \%)$ in the catalyst increased catalytic activity. Moreover, they developed a thermal treatment method for the catalyst that enhanced catalytic activity by increasing reduced $\mathrm{Rh}$ at the surface. They also mentioned that pellet size and amount of catalyst at constant contact time have no influence on catalytic activity. On the other hand, cerium (Ce) promoted catalyst containing nickel, cobalt, and hydrotalcite was developed by Ghungrud et al., for sorption enhanced $\mathrm{H}_{2} \mathrm{O}$ reforming of $\mathrm{CH}_{4}$. Ni and Co containing hydrotalcite were synthesized by the co-precipitation method for HT precursor and then the incipient wetness impregnation technique was applied for Ce promotion. Ce incorporation found to raise thermal stability and basicity. The developed catalyst enhanced $\mathrm{H}_{2}$ production and inhibited coke formation with good stability. Thus, the researchers concluded that Ce promoted Ni-Co-hydrotalcite is a potential catalyst for high purity $\mathrm{H}_{2}$ production.

\begin{tabular}{|c|c|c|c|c|c|}
\hline \multirow{2}{*}{$\begin{array}{l}\text { Catalyst } \\
\text { Applied }\end{array}$} & \multirow{2}{*}{$\begin{array}{l}\text { Synthesis } \\
\text { Method }\end{array}$} & \multirow{2}{*}{ Test Conditions } & Observations & \multirow{2}{*}{$\begin{array}{l}\mathrm{H}_{2} \\
\%\end{array}$} & \multirow{2}{*}{ Ref. } \\
\hline & & & Achievement & & \\
\hline Rh-Mg-Al & $\begin{array}{l}\text { Co-precipitation, } \\
\text { calcination and then } \\
\text { reduction }\end{array}$ & $750^{\circ} \mathrm{C}$ & $\begin{array}{l}\text { lower } \mathrm{Mg} / \mathrm{Al} \text { ratio provides higher With increasing } \mathrm{Rh} \% \text { in the } \\
\text { activity and doubling } \mathrm{Rh} \text { amount catalyst, the catalytic stability } \\
\text { increases methane conversion decreased }\end{array}$ & 77 & {$[80]$} \\
\hline
\end{tabular}

Table 2. Review report of HT derived catalyst for Steam/wet Reforming of Methane (SRM). 


\section{Continued}

\begin{tabular}{|c|c|c|c|c|c|c|}
\hline $\begin{array}{l}\text { Ce Tailored } \\
\text { Co-Ni/Htlc }\end{array}$ & $\begin{array}{l}\text { Co-precipitation, } \\
\text { calcination and finally } \\
\text { incipient wetness } \\
\text { impregnation for Ce } \\
\text { promotion }\end{array}$ & $500^{\circ} \mathrm{C} \& 0.1 \mathrm{MPa}$ & $\begin{array}{l}\text { Excellent } \mathrm{H}_{2} \text { productivity, better } \\
\mathrm{CO}_{2} \text { adsorption capacity, good } \\
\text { stability and inhibited coke } \\
\text { formation }\end{array}$ & $\begin{array}{l}\text { The activity of the catalyst } \\
\text { degrades after a certain } \\
\text { regeneration cycle due to metal } \\
\text { sintering }\end{array}$ & 90 & [79] \\
\hline $\begin{array}{l}\text { Hydrotalcite } \\
\text { (Htlc)-based Ni } \\
\text { with Ag }\end{array}$ & $\begin{array}{l}\text { Co-precipitation } \\
\text { followed by reduction } \\
\text { and calcination at } \\
600^{\circ} \mathrm{C} \text { for } 6 \mathrm{~h}\end{array}$ & $\begin{array}{l}670^{\circ} \mathrm{C} \& \\
\text { atmospheric } \\
\text { pressure }\end{array}$ & $\begin{array}{l}\mathrm{Ni} / \mathrm{Ag} \text { hydrotalcite catalyst has } \\
\text { good surface alloying }\end{array}$ & $\begin{array}{l}\text { Sites surrounding } \mathrm{Ag} \text { atom } \\
\text { found to be inactive to } \mathrm{C}-\mathrm{H} \\
\text { bonds of } \mathrm{CH}_{4} \text { and } \mathrm{Ag} \text { blocked } \\
\text { the more active sites in } \mathrm{Ni} \\
\text { nanoparticles }\end{array}$ & - & {$[76]$} \\
\hline $\begin{array}{l}\mathrm{Ce} \text { - and } \\
\text { Zr-doped Ni/ } \\
\text { hydrotalcite }\end{array}$ & $\begin{array}{l}\text { Co-precipitation, } \\
\text { calcination and then } \\
\text { incipient wetness } \\
\text { impregnation for } \mathrm{Zr} \\
\text { \& Ce promotions }\end{array}$ & $\begin{array}{l}673-873 \mathrm{~K} \& \\
0.1 \mathrm{MPa} \text { pressure }\end{array}$ & $\begin{array}{l}\mathrm{Ce} \text { and } \mathrm{Zr} \text { promoted } \\
\mathrm{Ni} / \text { hydrotalcite catalyst produced } \\
\text { high purity } \mathrm{H}_{2} \text { with good stability }\end{array}$ & $\begin{array}{l}\mathrm{Zr} \text { promoted catalyst has lower } \\
\text { stability then Ce promoted one }\end{array}$ & 97.1 & {$[93]$} \\
\hline $\mathrm{Ni} / \mathrm{Mg}-\mathrm{Al}$ & $\begin{array}{l}\text { Co-precipitation and } \\
\text { then calcination at } \\
850^{\circ} \mathrm{C} \text { for } 5 \mathrm{~h}\end{array}$ & $\begin{array}{l}650^{\circ} \mathrm{C} \& 0.1 \mathrm{MPa} \\
\text { Pressure }\end{array}$ & $\begin{array}{l}\mathrm{Ni} / \mathrm{Mg}-\mathrm{Al} \text { catalyst exhibited better } \\
\text { catalytic performance than the } \\
\text { conventional Ni/a- } \mathrm{Al}_{2} \mathrm{O}_{3} \text { and } \\
\mathrm{Ni} / \mathrm{g}-\mathrm{Al}_{2} \mathrm{O}_{3} \text { catalyst }\end{array}$ & $\begin{array}{l}\mathrm{CO}_{2} \text { selectivity decreased with } \\
\text { rising temperature }\end{array}$ & - & {$[94]$} \\
\hline $\begin{array}{l}\mathrm{Ni}-\mathrm{Htlc} \text { catalyst } \\
\text { and } \\
\mathrm{Ni}-\mathrm{CaO} / \mathrm{Al}_{2} \mathrm{O}_{3} \\
\text { Sorbent }\end{array}$ & $\begin{array}{l}\text { Co-precipitation \& } \\
\text { calcination for } \\
\text { catalyst and incipient } \\
\text { wetness impregnation } \\
\text { for sorbent }\end{array}$ & $\begin{array}{l}523 \mathrm{~K} \& 0.1 \mathrm{MPa} \\
\text { pressure }\end{array}$ & $\begin{array}{l}\text { Catalysts were viable for high } \\
\text { purity } \mathrm{H}_{2} \text { production and have } \\
\text { high stability }\end{array}$ & $\begin{array}{l}\text { Ni-Htlc catalyst showed short } \\
\text { breakthrough time and lower } \\
\text { adsorption capacity }\end{array}$ & 98.5 & {$[95]$} \\
\hline $\begin{array}{l}\mathrm{Ni} / \mathrm{MgAl}+ \\
\mathrm{CrFe}_{3} \mathrm{O}_{4}\end{array}$ & $\begin{array}{l}\text { Dry impregnation } \\
\text { followed by drying and } \\
\text { calcination } \\
\text { at } 500^{\circ} \mathrm{C} \text { for } 5 \mathrm{~h}\end{array}$ & $\begin{array}{l}500^{\circ} \mathrm{C}-700^{\circ} \mathrm{C} \& \\
1 \text { bar pressure }\end{array}$ & $\begin{array}{l}\mathrm{Ni} / \mathrm{MgAl}+\mathrm{Cr} / \mathrm{Fe}_{3} \mathrm{O}_{4} \text { mixed } \\
\text { catalyst exhibited improved } \mathrm{H}_{2} \\
\text { selectivity and } \mathrm{CH}_{4} \text { conversion }\end{array}$ & $\begin{array}{l}\text { Catalysts showed a rapid } \\
\text { decrease in } \mathrm{H}_{2} \\
\text { selectivity and } \mathrm{CH}_{4} \text { conversion } \\
\text { with the decrease of } \\
\text { temperature }\end{array}$ & - & {$[96]$} \\
\hline $\begin{array}{l}\mathrm{Ni} \text { and/or } \\
\text { Rusupported } \\
\text { hydrotalcite } \\
\text { material }\end{array}$ & $\begin{array}{l}\text { Incipient wetness } \\
\text { impregnation, then } \\
\text { drying and calcination } \\
\text { for } 5 \mathrm{~h} \text { at } 400^{\circ} \mathrm{C}\end{array}$ & $\begin{array}{l}700^{\circ} \mathrm{C} \& \\
1 \text { bar pressure }\end{array}$ & $\begin{array}{l}\text { The catalysts showed higher } \\
\text { methane conversions that } \\
\text { are almost similar to the values } \\
\text { predicted by thermodynamic } \\
\text { equilibrium and better resistance } \\
\text { to carbon deposition }\end{array}$ & $\begin{array}{l}\text { At high space velocities, the } \\
\text { product gas seems to has more } \\
\text { obstacles in reaching } \\
\text { thermodynamic equilibrium }\end{array}$ & - & {$[97]$} \\
\hline $\mathrm{Ru} / \mathrm{Ni}-\mathrm{Mg} / \mathrm{Al}$ & $\begin{array}{l}\text { Wet impregnation of } \\
\text { co-precipitated } \\
\mathrm{Ni}-\mathrm{Mg} / \mathrm{Al} \mathrm{Htlc} \mathrm{for} \\
\text { Ruincorporation }\end{array}$ & $450^{\circ} \mathrm{C}-800^{\circ} \mathrm{C}$ & $\begin{array}{l}\text { Catalysts with } \mathrm{Ru} \text { (ruthenium) } \\
\text { were active with no need } \\
\text { reduction pretreatment before } \\
\text { the test and the catalyst showed } \\
\text { better catalytic performance }\end{array}$ & $\begin{array}{l}\text { The surface area of the support } \\
\text { decreased with } \mathrm{Rh} \text { impregnation }\end{array}$ & & {$[98]$} \\
\hline $\begin{array}{l}\mathrm{Ni}-\mathrm{Htlc}+ \\
\text { Calcium } \\
\text { Aluminate }\end{array}$ & $\begin{array}{l}\text { Co-precipitation \& } \\
\text { calcination for Ni-Htlc } \\
\text { and pelletization of } \\
\text { Ca-based sorbent }\end{array}$ & $550^{\circ} \mathrm{C}$ & $\begin{array}{l}\text { The catalyst mixture produced } \\
\text { high purity } \mathrm{H}_{2}\end{array}$ & $\begin{array}{l}\text { Only the effect of sorbent } \\
\text { addition was studied }\end{array}$ & 99 & [99] \\
\hline $\begin{array}{l}\mathrm{Ni} / \mathrm{CaO}- \\
\text { Hydrotalcite }\end{array}$ & $\begin{array}{l}\text { Incipient wetness } \\
\text { impregnation, then } \\
\text { drying and calcination } \\
\text { at } 900^{\circ} \mathrm{C} \text { for } 4 \mathrm{~h}\end{array}$ & $400^{\circ} \mathrm{C}-600^{\circ} \mathrm{C}$ & $\begin{array}{l}\text { High } \mathrm{H}_{2} \text { concentration of } 80 \% \\
\text { was achieved at low temperature } \\
\left(600^{\circ} \mathrm{C}\right)\end{array}$ & $\begin{array}{l}\text { The developed catalyst showed } \\
\text { less activity than } \mathrm{Ni} / \mathrm{Al}_{2} \mathrm{O}_{3} \\
\text { catalyst }\end{array}$ & 80 & {$[100]$} \\
\hline $\begin{array}{l}\mathrm{Pt} / \mathrm{Htlc} \\
(\mathrm{Ni}-\mathrm{Mg}-\mathrm{Al})\end{array}$ & $\begin{array}{l}\text { Wet impregnation of } \\
\text { calcined } \\
\mathrm{Mg} / \mathrm{Al}-\mathrm{Htl} \text { for } \mathrm{Ni} \text { and } \\
\mathrm{Pt} \text { doping }\end{array}$ & $700^{\circ} \mathrm{C}$ & $\begin{array}{l}\text { Pt-Ni alloying on the surface } \\
\text { of the catalyst } \\
\text { caused self-regeneration and } \\
\text { self-activation via reversible redox } \\
\text { between } \mathrm{Ni}^{\circ} \text { and } \mathrm{Ni}^{2+} \text { by } \mathrm{H}_{2} \\
\text { spillover from } \mathrm{Pt}\end{array}$ & $\begin{array}{l}\mathrm{CH}_{4} \text { conversion over the } \\
\text { developed catalyst was not } \\
\text { compared precisely }\end{array}$ & - & {$[101]$} \\
\hline
\end{tabular}


Wang et al., studied the role of bimetallic alloys in SRM reaction. They synthesized hydrotalcite catalyst containing $\mathrm{Ni}$ and $\mathrm{Ag}$ to study the effect of $\mathrm{Ni} / \mathrm{Ag}$ alloying on SRM. According to their research, a silver (Ag) atom can influence seven nearby sites and those sites are found to be inactive to $\mathrm{C}-\mathrm{H}$ bonds of $\mathrm{CH}_{4}$ and Ag blocked the more active sites in the edges and steps of Ni nano-particles. Though, Ni/Ag hydrotalcite catalyst has better surface alloying than other bimetallic catalysts. Elsewhere cerium ( $\mathrm{Ce}$ ) and zirconium (Zr) was used to promote $\mathrm{Ni} /$ hydrotalcite catalyst to evaluate its performance in SRM by Dewoolkar et al., [113]. High basicity and large surface area of the doped catalyst restricted unwanted reactions and coke formation. The developed catalysts, especially Ce doped hydrotalcite catalyst exhibited improved $\mathrm{H}_{2}$ production and stability. According to their findings, the researchers concluded that $\mathrm{Ce}$ and $\mathrm{Zr}$ are the potential promoters for $\mathrm{Ni} /$ hydrotalcite catalysts to produce pure $\mathrm{H}_{2}$.

Hydrotalcite type $\mathrm{Ni} / \mathrm{Mg}-\mathrm{Al}$ catalyst for wet reforming of methane was investigated by Qi et al., [114]. Their study reviled that $\mathrm{Ni} / \mathrm{Mg}-\mathrm{Al}$ catalyst has good stability and higher activity than $\mathrm{Ni} / \gamma-\mathrm{Al}_{2} \mathrm{O}_{3}$ and $\mathrm{Ni} / \alpha-\mathrm{Al}_{2} \mathrm{O}_{3}$ catalysts. Where, $\mathrm{Ni} / \mathrm{Mg}-\mathrm{Al}$ catalyst containing $\mathrm{Ni} / \mathrm{Al} / \mathrm{Mg}$ molar ratio of $0.5: 1.0: 2.5$ showed the best activity. They also observed that raising temperature favors $\mathrm{CH}_{4}$ conversion, but $\mathrm{CO}_{2}$ selectivity enhanced at low temperatures. Ni-based hydrotalcite catalyst (Ni-HT) was also studied by Dewoolkar et al., [115]. Their hybrid catalytic material comprised of Ni-HT (Ni-hydrotalcite) catalyst and $\mathrm{Ni}-\mathrm{CaO} / \mathrm{Al}_{2} \mathrm{O}_{3}$ sorbent. Their developed catalytic mix was able to produce high purity $\mathrm{H}_{2}$ with good stability. Thus, a conclusion was brought that, the multifunctional hybrid material ( $\mathrm{Ni}-\mathrm{Htlc}$ and $\mathrm{Ni}-\mathrm{CaO} / \mathrm{Al}_{2} \mathrm{O}_{3}$ ) is a viable catalyst for pure hydrogen production from sorption enhanced steam/wet reforming of methane. Kim and co-researchers [116] also studied Ni-hydrotalcite based mixed catalyst containing $\mathrm{Ni} / \mathrm{MgAl}$ and $\mathrm{Cr} / \mathrm{Fe}_{3} \mathrm{O}_{4}$. By using the catalyst in SRM process high $\mathrm{H}_{2}$ and $\mathrm{CO}$ selectivity coupled with better $\mathrm{CH}_{4}$ conversion were reported. It was also reported that $\mathrm{Cr} / \mathrm{Fe}_{3} \mathrm{O}_{4}$ as a catalyst enhanced WGS reaction. On the other hand, Hydrotalcite catalyst promoted with nickel $(\mathrm{Ni})$ and ruthenium $(\mathrm{Ru})$ was studied by Velasco and co-workers [117]. According to the study, hydrotalcite derived $\mathrm{Ni} / \mathrm{Rh}$ bimetallic catalyst was more resistant to carbon deposition then only Ni containing catalysts. They also reported higher $\mathrm{CH}_{4}$ conversion that was close to values assumed by thermodynamic equilibrium. $\mathrm{Ru}$ supported $\mathrm{Ni}-\mathrm{Mg}$ - $\mathrm{Al}$ (hydrotalcite) catalyst for the SRM process was also studied by Nawfal et al., [118]. Ru impregnation was found to increase the reactivity of oxides and $\mathrm{CH}_{4}$ conversion during SRM. $\mathrm{Rh}$ doped $\mathrm{Ni}-\mathrm{Mg} / \mathrm{Al}$ catalyst was reported to exhibit better stability and catalytic activity.

Nickel hydrotalcite coupled with calcium aluminate catalytic system for high purity $\mathrm{H}_{2}$ production from sorption enhanced SRM was examined by Broda et al., [119]. Ni-hydrotalcite catalyst and calcium aluminate sorbent were able to produce highly pure hydrogen ( $99 \mathrm{vol} \%)$. The calcium aluminate sorbent demonstrated high cyclic $\mathrm{CaO}$ conversion and good stability which enhanced $\mathrm{H}_{2}$ productivity. For high $\mathrm{H}_{2}$ productivity from sorption enhanced SRM Chanbura- 
nasiri et al., [120] also developed hydrotalcite based catalyst containing $\mathrm{Ni}$ and $\mathrm{CaO}$. At steam, to methane ratio 3 , temperature $600^{\circ} \mathrm{C}$ and atmospheric pressure the catalytic system offered a high $\mathrm{H}_{2}$ concentration of $80 \%$. It was also mentioned that $\mathrm{CO}_{2}$ absorption can improve reaction conditions only if the catalyst is active enough. Finally, commercial hydrotalcite $(\mathrm{Mg}-\mathrm{Al})$ promoted with nickel $(\mathrm{Ni})$ and platinum $(\mathrm{Pt})$ as an intelligent catalyst was evaluated by Zhan et al., [121] for SRM. The developed catalyst exhibited self-activation and self-regeneration properties. Well crystallized alloying between $\mathrm{Pt}-\mathrm{Ni}$ and $\mathrm{Mg}(\mathrm{Al}) \mathrm{O}$ on the catalyst surface enhanced self-activation and self-regeneration. According to the above-mentioned discussion, $\mathrm{Ni}$ containing hydrotalcite ( $\mathrm{Ni}-\mathrm{HT}$ ) is a promising catalyst for $\mathrm{H}_{2}$ via steam reforming of methane. It was tried to further enhance the catalytic activity by doping Ni-Htlc with promoters like $\mathrm{Rh}, \mathrm{Ce}, \mathrm{Zr}, \mathrm{Ag}, \mathrm{Pt}$, $\mathrm{Ru}$, etc. Among the promoted catalysts: Ce doped Ni-hydrotalcite (Ce/Ni-HT) catalyst excellent better results and the researcher referred that the catalyst has the potentiality to be used in the SRM process for a large scale $\mathrm{H}_{2}$ production. In conformity with Table 2 hydrogen productivity from SRM when HT derived catalysts were used is presented below in Figure 1 .

\subsection{HT Derived Catalysts for Methanol Steam Reforming}

Methanol is a promising fuel and it is considered as an attractive hydrogen storage medium as the gravimetric hydrogen density of $\mathrm{CH}_{3} \mathrm{OH}$ is much higher than that of compressed or liquid hydrogen [122]. The use of methanol for hydrogen storage is advantageous as the necessity of cryogenic or pressurized containers can be avoided. The liberation of hydrogen for methanol can be done by several catalytic reactions such as methanol decomposition, WGS (water gas shift) reaction, methanol steam reforming and partial oxidation of $\mathrm{CH}_{3} \mathrm{OH}$. Among these reactions, methanol steam reforming reaction is more convenient for $\mathrm{H}_{2}$ production due to low operational temperature $\left(300^{\circ} \mathrm{C}-400^{\circ} \mathrm{C}\right)$, no direct $\mathrm{CO}$ production and highest $\mathrm{H}_{2}$ concentration in the product stream [123]. The reaction for $\mathrm{CH}_{3} \mathrm{OH}$ steam reforming is presented in Equation (4) below.

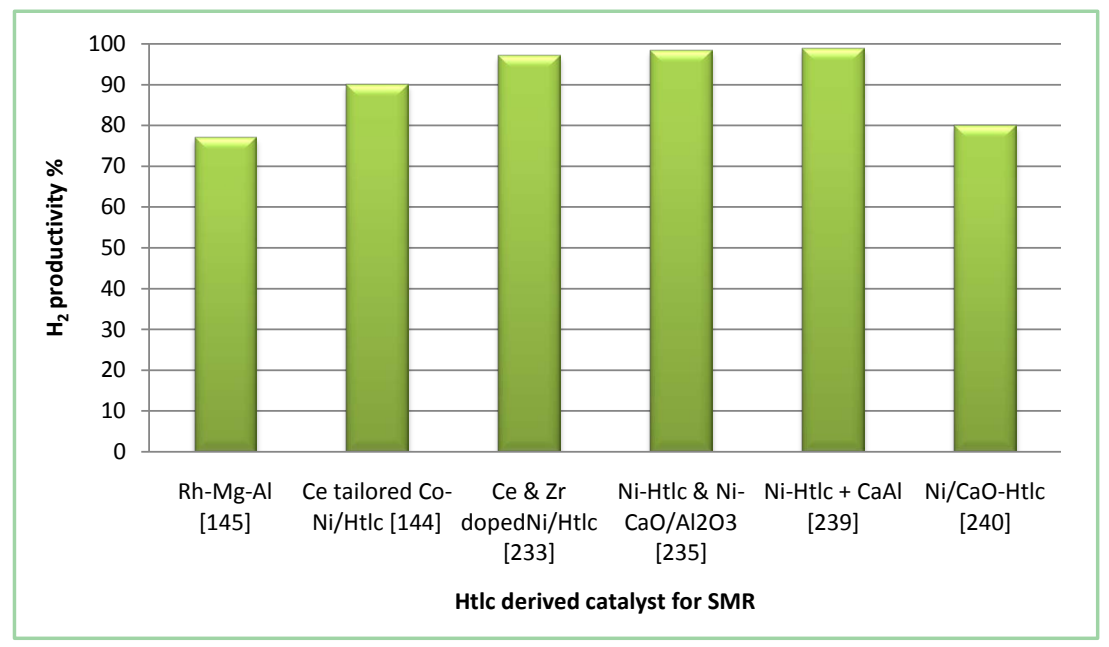

Figure 1. Performance of different HT based catalysts during SMR. 


$$
\mathrm{CH}_{3} \mathrm{OH}+\mathrm{H}_{2} \mathrm{O} \rightarrow \mathrm{CO}_{2}+3 \mathrm{H}_{2} ; \Delta \mathrm{H}=+49 \mathrm{KJ} / \mathrm{mol}
$$

However, obstacles like high endothermicity and rapid speed variation of methanol steam reforming reaction affect $\mathrm{H}_{2}$ production. To overcome these problems partial oxidation methods and effective catalysts are used [124]. Broadly applied catalysts for $\mathrm{CH}_{3} \mathrm{OH}$ steam reforming are zinc oxide, copper, and alumina containing materials which are usually synthesized via co-precipitation method from malachite-boehmite precursor [125]. Hydrotalcite derived materials having copper $(\mathrm{Cu})$, zinc $(\mathrm{Zn})$ and aluminum $(\mathrm{Al})$ are found to have potential applications as a catalyst for methanol steam reforming [126]. In recent years, researchers experimented with hydrotalcite $(\mathrm{Htll})$ based catalysts containing different $\mathrm{Zn}, \mathrm{Cu}$, and $\mathrm{Al}$ ratios and metal promoted $\mathrm{Zn}, \mathrm{Cu}, \mathrm{Al}-\mathrm{Htlc}$ catalysts for enhancing productivity during methanol steam reforming. Table 3 presents the catalytic activity and overall performance study of hydrotalcite derived catalysts for $\mathrm{CH}_{3} \mathrm{OH}$ steam reforming.

According to Table 3 Yang et al., [127] studied the influence of rare earth metals (Ce, La, Sm, Y, and $\mathrm{Gb}$ ) on the performance of $\mathrm{Cu} / \mathrm{Zn}-\mathrm{Al}-\mathrm{Htlc}$ catalyst for $\mathrm{CH}_{3} \mathrm{OH}$ steam reforming. They utilized the in-situ method on $\gamma-\mathrm{Al}_{2} \mathrm{O}_{3}$ for hydrotalcite precursor $(\mathrm{Cu} / \mathrm{ZnAl}-\mathrm{Htl} \mathrm{c})$ synthesis and then modified the precursor with rare earth metals (Ce, La, Sm, Y, and $\mathrm{Gb}$ ) by wet impregnation technique. The researchers found that the performance of $\mathrm{Cu} / \mathrm{Zn}$-Al-Htlc catalyst is dependent on the reducibility and surface area of $\mathrm{Cu}$. Moreover, the addition of $\mathrm{Ce}, \mathrm{Sm}$ and $\mathrm{Gb}$ further enhanced the catalytic activity of $\mathrm{Cu} / \mathrm{Zn}-\mathrm{Al}-\mathrm{Htlc}$ catalyst. Among their developed catalysts, $\mathrm{Ce}-\mathrm{Cu} / \mathrm{ZnAl}-\mathrm{Htlc}$ exhibited better results with high activity, $100 \%$ methanol conversion and very low CO concentration $(0.39 \%)$ in the product. He et al., [128] also used the in-situ and wet impregnation method to synthesized $\mathrm{Cu}$ supported $\mathrm{ZnAl}-\mathrm{Htlc}$ catalyst for $\mathrm{CH}_{3} \mathrm{OH}$ steam reforming. The developed copper supported $\mathrm{Zn}-\mathrm{Al}-\mathrm{Htlc}$ catalyst was able to convert $99.98 \% \mathrm{CH}_{4}$ at $300^{\circ} \mathrm{C}$ with the $\mathrm{H}_{2}$ production rate of $981 \mathrm{~cm}^{3} \mathrm{~kg}^{-1} \mathrm{~s}^{-1}$. Then again, Kim et al., [129] utilized the co-precipitation process to develop $\mathrm{Cu}-\mathrm{Al}$ based catalysts from hydrotalcite for utilization in methanol steam reforming. The developed hydrotalcite derived catalyst containing $\mathrm{Cu}, \mathrm{Ni}, \mathrm{Zn}$, and $\mathrm{Al}$ was able to convert $76 \% \mathrm{CH}_{3} \mathrm{OH}$. They mentioned that $\mathrm{Ni}$ incorporation slightly increased the catalytic performance of the developed catalyst.

The mixed catalyst containing $\mathrm{CuO} / \mathrm{ZnO} / \mathrm{Al}_{2} \mathrm{O}_{3}$ and $\mathrm{K}-\mathrm{HT}$ (potassium promoted hydrotalcite) was evaluated by Xiang $\mathrm{Wu}$ and Sufang $\mathrm{Wu}$ [130] for the production of highly pure $\mathrm{H}_{2}$ from sorption-enhanced methanol steam reforming. It was able to obtain $98.36 \% \mathrm{H}_{2}$ in the product stream. Also found that the introduction of $\mathrm{K}-\mathrm{HT}$ reduced the $\mathrm{Me}-\mathrm{OH}$ (methanol) conversion temperature to nearly $50^{\circ} \mathrm{C}$ and increased the hydrogen concentration over $20 \%$ in the product stream. Copper supported zinc-aluminum hydrotalcite $(\mathrm{Cu} / \mathrm{Zn}-\mathrm{Al}-\mathrm{Htlc})$ catalyst for $\mathrm{CH}_{3} \mathrm{OH}$ steam reforming was evaluated by Hammoud and co-workers [131]. Co-precipitation (for HT precursor) and wet impregnation (for $\mathrm{Cu}$ support) technique was applied for the catalyst development. Among the developed 
Table 3. Review report of HT derived catalysts for $\mathrm{CH}_{3} \mathrm{OH}$ Steam Reforming.

\begin{tabular}{|c|c|c|c|c|c|c|}
\hline \multirow{2}{*}{$\begin{array}{l}\text { Catalysts } \\
\text { Applied }\end{array}$} & \multirow{2}{*}{ Synthesis Process } & \multirow{2}{*}{$\begin{array}{l}\text { Test } \\
\text { Parameter }\end{array}$} & \multicolumn{2}{|l|}{ Observations } & \multirow{2}{*}{$\begin{array}{l}\mathrm{CH}_{3} \mathrm{OH} \\
\text {-conversion } \\
\%\end{array}$} & \multirow{2}{*}{ Ref. } \\
\hline & & & Achievements & Limitations & & \\
\hline $\begin{array}{l}\mathrm{Ce}, \mathrm{La}, \mathrm{Sm}, \mathrm{Y} \text {, and } \\
\mathrm{Gb} \text { promoted } \\
\mathrm{Cu} / \mathrm{Zn}-\mathrm{Al}-\mathrm{Htlc}\end{array}$ & $\begin{array}{l}\text { In-situ synthesis for } \\
\text { catalyst precursor and } \\
\text { wet impregnation for } \\
\text { doping }\end{array}$ & $250^{\circ} \mathrm{C}$ & $\begin{array}{l}\mathrm{Ce} / \mathrm{Cu} / \mathrm{ZnAl} \text { hydrotalcite } \\
\text { catalyst exhibited high activity, } \\
\text { methanol conversion of } 100 \% \\
\text { and low } \mathrm{CO} \text { concentration }\end{array}$ & $\begin{array}{l}\mathrm{La} / \mathrm{Cu} / \mathrm{ZnAl} \text { and } \mathrm{Y} / \mathrm{Cu} / \mathrm{ZnAl} \\
\text { catalysts have inferior } \\
\text { performances because of } \\
\text { smaller surface area of } \\
\text { copper and higher reduction } \\
\text { temperatures }\end{array}$ & 100 & [127] \\
\hline $\begin{array}{l}\text { Cu supported } \\
\mathrm{ZnAl}-\mathrm{Htlc} / \\
\gamma-\mathrm{Al}_{2} \mathrm{O}_{3}\end{array}$ & $\begin{array}{l}\text { In-situ synthesis for } \\
\text { catalyst precursor and } \\
\text { wet impregnation for } \\
\mathrm{Cu} \text { support }\end{array}$ & $300^{\circ} \mathrm{C}$ & $\begin{array}{l}\mathrm{Cu} \text { incorporation enhanced } \\
\text { reducibility and catalytic activity }\end{array}$ & $\begin{array}{l}\text { Higher } \mathrm{Cu} \text { incorporation } \\
(>10 \%) \text { decreased methanol } \\
\text { conversion }\end{array}$ & 99.98 & [128] \\
\hline $\begin{array}{l}\mathrm{Cu}, \mathrm{Ni}, \mathrm{Zn} \text {, and } \\
\text { Albased } \\
\text { hydrotalcite }\end{array}$ & $\begin{array}{l}\text { Co-precipitation } \\
\text { followed by calcination } \\
\text { at } 400^{\circ} \mathrm{C} \text { for } 1 \mathrm{~h}\end{array}$ & $220^{\circ} \mathrm{C}-260^{\circ} \mathrm{C}$ & $\begin{array}{l}\text { The developed } \\
\mathrm{Cu}_{0.75} \mathrm{Al}_{0.25} \text { catalyst showed better } \\
\text { activity, active metal dispersion } \\
\text { and methanol conversion than } \\
\text { the benchmark catalyst }\end{array}$ & $\begin{array}{l}\text { At higher operational } \\
\text { temperatures CO } \\
\text { concentration increased } \\
\text { considerably }\end{array}$ & 76 & [129] \\
\hline $\begin{array}{l}\mathrm{CuO} / \mathrm{ZnO} / \\
\mathrm{Al}_{2} \mathrm{O}_{3} \text { and } \mathrm{K}-\mathrm{Htlc}\end{array}$ & $\begin{array}{l}\text { Calcination of parched } \\
\mathrm{Htlc} \text { at } 400^{\circ} \mathrm{C} \text { for } 4 \mathrm{~h} \\
\text { then dry impregnation } \\
\text { for } \mathrm{K} \text { loading }\end{array}$ & $230^{\circ} \mathrm{C}$ & $\begin{array}{l}\text { Catalyst with } \mathrm{K}-\mathrm{Htl} \text { absorbent } \\
\text { was able to convert } \mathrm{CH}_{3} \mathrm{OH} \text { at } \\
\text { lower temperatures and the } \\
\text { product gas contained } 99.16 \% \\
\mathrm{H}_{2} \text { and only } 0.39 \% \mathrm{CO}\end{array}$ & $\begin{array}{l}\text { High regeneration } \\
\text { temperature of the absorbent } \\
\text { caused sintering of the } \\
\text { catalyst }\end{array}$ & & {$[130]$} \\
\hline $\begin{array}{l}\mathrm{Cu} / \mathrm{Zn}-\mathrm{Al} \\
\text { Hydrotalcite }\end{array}$ & $\begin{array}{l}\text { Co-precipitation for } \\
\mathrm{Zn} \text {-Al Htlc and wet } \\
\text { impregnation for } \mathrm{Cu} \\
\text { incorporation }\end{array}$ & $200^{\circ} \mathrm{C}-350^{\circ} \mathrm{C}$ & $\begin{array}{l}\text { Catalyst with } 10 \% \text { Cu performed } \\
99.78 \% \text { methanol conversion }\end{array}$ & $\begin{array}{l}\text { Compromise between } \\
\text { reducibility dispersion of } \mathrm{Cu} \\
\text { species has to be made for } \\
\text { good catalytic performance } \\
\text { and low CO generation }\end{array}$ & 99.78 & [131] \\
\hline $\mathrm{Cu} / \mathrm{Zn}-\mathrm{Al}-\mathrm{Htlc}$ & $\begin{array}{l}\text { Co-precipitation inside } \\
\text { microemulsion } \\
\text { droplets and then } \\
\text { calcination in the air } \\
\text { for } 3 \mathrm{~h} \text { at } 330^{\circ} \mathrm{C}\end{array}$ & $260^{\circ} \mathrm{C}$ & $\begin{array}{l}\text { Catalyst developed by } \\
\text { micro-emulsion technique } \\
\text { exhibited improved catalytic } \\
\text { performances during } \mathrm{CH}_{3} \mathrm{OH} \\
\text { steam reforming }\end{array}$ & $\begin{array}{l}\text { Micro-emulsion } \\
\text { produced catalyst with poor } \\
\text { intrinsic activity }\end{array}$ & 69 & {$[132]$} \\
\hline $\begin{array}{l}\text { PdZn-Htlc, } \\
\text { Pd }_{2} \text { Ga-Htlc, and } \\
\text { Pd-Htlc }\end{array}$ & $\begin{array}{l}\text { Co-precipitation for } \\
\text { Htlc and reductive } \\
\text { decomposition for } \\
\text { intermetallic support } \\
\text { incorporation }\end{array}$ & $200^{\circ} \mathrm{C}-300^{\circ} \mathrm{C}$ & $\begin{array}{l}\text { Intermetallic nanoparticle } \\
\text { supported Htlc catalyst exhibited } \\
\text { improved catalytic activity and } \\
\text { selectivity. Where } \mathrm{Pd}_{2} \mathrm{Ga}-\mathrm{Htll} \\
\text { catalyst showed the best } \\
\text { result }\end{array}$ & $\begin{array}{l}\text { The activity of the } \\
\text { intermetallic } \mathrm{Htlc} \text { catalyst } \\
\text { was less than } \mathrm{Cu} / \mathrm{ZnOH} \mathrm{Hllc} \\
\text { catalyst }\end{array}$ & 9.5 & [133] \\
\hline
\end{tabular}

$\mathrm{Cu} / \mathrm{Zn}$-Al-HT catalysts, $10 \% \mathrm{Cu}$ containing $\mathrm{HT}$ showed the best result and it exhibited an $\mathrm{H}_{2}$ yield of $75.44 \%$ at $250^{\circ} \mathrm{C}$ with $51.87 \%$ methanol conversion. Moreover, it was able to convert $99.78 \% \mathrm{Me}-\mathrm{OH}$ at $350^{\circ} \mathrm{C}$. It was also found that catalytic activity and reaction efficiency were dependent on the amount $\mathrm{Cu}_{2} \mathrm{O}$ that was present in the enhanced catalyst. $\mathrm{Cu}, \mathrm{Zn}, \mathrm{Al}-\mathrm{HT}$ catalyst for $\mathrm{CH}_{3} \mathrm{OH}$ steam reforming was also studied by Kuhl et al., [132]. They used the microemulsion technique for catalyst synthesis. The researchers were able to reduce the embedding of the copper particles and increase the copper surface area by applying the micro-emulsion technique. Thus, higher catalytic activity was achieved 
during $\mathrm{CH}_{3} \mathrm{OH}$ steam reforming by the developed catalyst. Finally, $\mathrm{Pd}_{2} \mathrm{Ga}$ and PdZn intermetallic nanoparticles supported hydrotalcite catalyst for $\mathrm{CH}_{3} \mathrm{OH}$ steam reforming were synthesized by Ota et al., [133]. The researchers found that the $\mathrm{Ga}$ presence in the catalyst increased selectivity towards $\mathrm{Me}-\mathrm{OH}$ and $\mathrm{CO}_{2}$. However, the intermetallic nano-particles supported hydrotalcite catalyst was less active to $\mathrm{Me}-\mathrm{OH}$ steam reforming then $\mathrm{Cu}-\mathrm{ZnO}$-Hydrotalcite based catalyst.

Hydrotalcite derived catalysts showed high $\mathrm{Me}-\mathrm{OH}$ conversion and hydrogen productivity in methanol steam reforming. Especially, copper-containing hydrotalcite catalysts showed excellent performance. Methanol conversion by catalysts mentioned in Table 3 is presented in Figure 2.

\subsection{HT Based Catalysts for Ethanol Steam Reforming}

Nowadays, ethanol $\left(\mathrm{C}_{2} \mathrm{H}_{5} \mathrm{OH} / \mathrm{Et}-\mathrm{OH}\right)$ has become a potential source of hydrogen $\left(\mathrm{H}_{2}\right)$. Ethanol for hydrogen production is advantageous than natural gas and liquefied petroleum as it is renewable (bio-ethanol), non-toxic, easy to handle and high hydrogen yield [134]. Hydrogen from ethanol can be produced by partial oxidation, steam reforming or oxidative reforming method. Among these methods, ethanol steam reforming has a higher $\mathrm{H}_{2}$ yield as part of it comes from Steam. Moreover, ethanol steam reforming is easy to apply process. Equations (5) and (6) present the prime reactions of ethanol steam reforming.

$$
\begin{gathered}
\mathrm{C}_{2} \mathrm{H}_{5} \mathrm{OH}+\mathrm{H}_{2} \mathrm{O} \rightarrow 2 \mathrm{CO}+4 \mathrm{H}_{2} ; \Delta \mathrm{H}=+256 \mathrm{KJ} / \mathrm{mol} \\
\mathrm{C}_{2} \mathrm{H}_{5} \mathrm{OH}+3 \mathrm{H}_{2} \mathrm{O} \rightarrow 2 \mathrm{CO}_{2}+6 \mathrm{H}_{2} ; \Delta \mathrm{H}=+174 \mathrm{KJ} / \mathrm{mol}
\end{gathered}
$$

However, $\mathrm{C}_{2} \mathrm{H}_{5} \mathrm{OH}$ steam reforming is a complicated process, where the number of reactions such as dehydrogenation, dehydration, coking, and decomposition can take place successively or even simultaneously [135]. Temperature management during $\mathrm{C}_{2} \mathrm{H}_{5} \mathrm{OH}$ steam reforming is a significant issue due to the endothermic nature of ethanol steam reforming reaction and the necessity of continuous heat supply [136]. Moreover, methane formation during ethanol steam reforming Equation (7) decreases $\mathrm{H}_{2}$ yield.

$$
\mathrm{C}_{2} \mathrm{H}_{5} \mathrm{OH} \rightarrow \mathrm{H}_{2}+\mathrm{CO}+\mathrm{CH}_{4}
$$

To overcome such obstacles, catalysts can play an important role. Catalysts can effectively reduce operating temperature and prevent methane formation [84] [137]. Previous studies revealed that noble metal-derived catalysts exhibited good results for ethanol $\mathrm{H}_{2} \mathrm{O}$ reforming [138]. However, noble metal-based catalysts become deactivated over time during ethanol steam reforming due to the carbonaceous material deposition on the surface of the catalyst. The incorporation of catalytic support that can neutralize the acidic sites of the catalyst can solve the problem [84] [136]. Hydrotalcite with basic sites in its structure is a potential catalyst precursor for ethanol steam reforming [139] [140]. Metallic elements $(\mathrm{Ni}, \mathrm{Co}, \mathrm{K}, \mathrm{La}, \mathrm{Cu}, \mathrm{Rh}$, and $\mathrm{Fe}$, etc.) used in $\mathrm{HT}$ to ease the conditions of ethanol steam reforming and enhance product yield that tabulated in Table 4. 


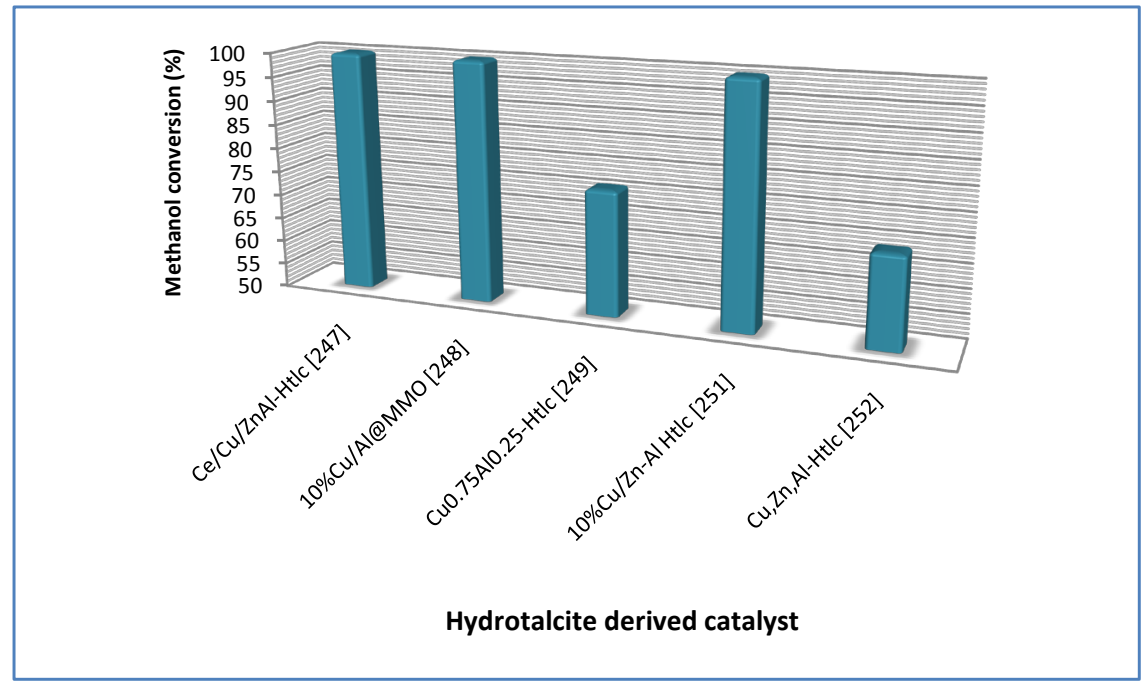

Figure 2. Methanol conversion by HT based catalysts in methanol steam reforming.

Table 4. Review report of HT derived catalyst for Ethanol Steam Reforming.

\begin{tabular}{|c|c|c|c|c|c|c|}
\hline \multirow{2}{*}{ Catalyst } & \multirow{2}{*}{ Synthesis Method } & \multirow{2}{*}{$\begin{array}{l}\text { Test } \\
\text { Parameters }\end{array}$} & \multicolumn{2}{|l|}{ Observations } & \multirow{2}{*}{$\begin{array}{l}\mathrm{H}_{2} \\
\%\end{array}$} & \multirow{2}{*}{ Ref. } \\
\hline & & & Achievements & Limitations & & \\
\hline $\begin{array}{l}\text { Co \& La supported } \\
\text { Zn, Al-Htlc }\end{array}$ & $\begin{array}{l}\text { Co-precipitation } \\
\text { followed by calcination } \\
\text { at } 600^{\circ} \mathrm{C} \text { for } 3 \mathrm{~h}\end{array}$ & $\begin{array}{l}400^{\circ} \mathrm{C}-600^{\circ} \mathrm{C} \& \\
\text { atmospheric } \\
\text { pressure }\end{array}$ & $\begin{array}{l}\text { Better EtOH conversion, high } \\
\mathrm{H}_{2} \text { selectivity, and good catalyst } \\
\text { stability }\end{array}$ & $\begin{array}{l}\text { EtOH conversion decreased } \\
\text { at a lower temperature }\end{array}$ & 75.1 & [32] \\
\hline $\begin{array}{l}\mathrm{NiCo}-\mathrm{MgAl} \text { mixed } \\
\text { oxide prepared } \\
\text { from } \mathrm{Htlc}\end{array}$ & $\begin{array}{l}\text { Ultrasound or } \\
\text { microwave radiation } \\
\text { assisted } \\
\text { co-precipitation } \\
\text { followed by thermal } \\
\text { decomposition at } \\
500^{\circ} \mathrm{C} \text { for } 16 \mathrm{~h}\end{array}$ & $550^{\circ} \mathrm{C}$ & $\begin{array}{l}\text { Ultrasound or microwave } \\
\text { treatment reduced catalyst } \\
\text { synthesis time and increased } \\
\text { reducibility and basicity of the } \\
\text { catalyst }\end{array}$ & $\begin{array}{l}\text { Increase in basicity } \\
\text { decreased } \mathrm{H}_{2} \text { yield due to } \\
\text { the formation of unwanted } \\
\text { byproducts }\end{array}$ & 77 & [141] \\
\hline Co-Mg-Al & $\begin{array}{l}\text { Ultrasound-assisted } \\
\text { co-precipitation } \\
\text { followed by calcination } \\
\text { at } 600^{\circ} \mathrm{C} \text { for } 8 \mathrm{~h}\end{array}$ & $\begin{array}{l}600^{\circ} \mathrm{C} \& \\
\text { atmospheric } \\
\text { pressure }\end{array}$ & $\begin{array}{l}\text { Catalysts with } 10 \% \text { to } 15 \% \text { Co } \\
\text { exhibited the best hydrogen } \\
\text { yield due to good dispersion of } \\
\text { active phase, large surface area } \\
\text { and non-agglomeration of the } \\
\text { catalyst }\end{array}$ & $\begin{array}{l}\text { Co concentrations less than } \\
10 \% \text { promotes unwanted } \\
\text { product formation and } \\
\text { rapid catalyst deactivation }\end{array}$ & - & [142] \\
\hline $\begin{array}{l}\text { K doped } \\
\mathrm{Co} / \mathrm{Mg} / \mathrm{Al}-\mathrm{Htlc}\end{array}$ & $\begin{array}{l}\text { Co-precipitation for } \\
\text { Htlc precursor and wet } \\
\text { impregnation for } \mathrm{K} \\
\text { doping followed by } \\
\text { calcination at } 550^{\circ} \mathrm{C} \\
\text { for } 4 \mathrm{~h}\end{array}$ & $\begin{array}{l}400-600^{\circ} \mathrm{C} \& \\
1-18 \text { bar } \\
\text { pressure }\end{array}$ & $\begin{array}{l}\text { K doped Co-Htlc catalyst } \\
\text { exhibited good stability and } \\
\text { no } \mathrm{C} \text { accumulation happened } \\
\text { during the catalytic operation }\end{array}$ & $\begin{array}{l}\text { Staged membrane reactor } \\
\text { exhibited lower } \mathrm{H}_{2} \text { yields } \\
\text { because of the } \mathrm{H}_{2} \text { removal } \\
\text { from the reaction medium }\end{array}$ & 80 & [143] \\
\hline $\mathrm{Ni}-\mathrm{Mg} / \mathrm{Al}-\mathrm{Htlc}$ & $\begin{array}{l}\text { Co-precipitation and } \\
\text { then calcination for } \\
4 \mathrm{~h} \text { at } 500^{\circ} \mathrm{C} \text { in air }\end{array}$ & $200^{\circ} \mathrm{C}-650^{\circ} \mathrm{C}$ & $\begin{array}{l}\text { In dilute condition }(3 \% \mathrm{EtOH}) \\
\text { catalyst reduced at } 450^{\circ} \mathrm{C} \text { with } \\
\mathrm{H}_{2} \text { provided completeEtOH } \\
\text { conversion and } \mathrm{CO} \text { free } \mathrm{H}_{2} \\
\text { production }\end{array}$ & $\begin{array}{l}\text { At higher temperatures, } \\
\text { ethanol conversion } \\
\text { decreased and amount of } \\
\text { CO in the product stream } \\
\text { increased }\end{array}$ & 76 & [144] \\
\hline $\begin{array}{l}\text { Shell core } \\
\mathrm{La}-\mathrm{Ni}(\mathrm{Mg}-\mathrm{AL}) \mathrm{O}_{3} \\
\text { at } \mathrm{Mg}-\mathrm{Al}\end{array}$ & $\begin{array}{l}\text { Co-precipitation } \\
\text { followed by calcination } \\
\text { at } 700^{\circ} \mathrm{C}-900^{\circ} \mathrm{C} \text { for } \\
6 \mathrm{~h}\end{array}$ & $\begin{array}{l}700^{\circ} \mathrm{C} \& \\
\text { Atmospheric } \\
\text { pressure }\end{array}$ & $\begin{array}{l}\text { The developed shell-core } \\
\text { catalyst at temperature } \geq 700^{\circ} \mathrm{C} \\
\text { showed good stability and high } \\
\text { activity during EtOH steam } \\
\text { reforming }\end{array}$ & $\begin{array}{l}\text { Catalyst calcined at high } \\
\text { temperature }\left(900^{\circ} \mathrm{C}\right) \text { caused } \\
\text { the spinel phase and coke } \\
\text { formation during the } \\
\text { reaction }\end{array}$ & $\begin{array}{l}4.0 \\
\mathrm{~mol} / \mathrm{mo} \\
1 \mathrm{Et}-\mathrm{OH}\end{array}$ & 5] \\
\hline
\end{tabular}




\section{Continued}

\begin{tabular}{|c|c|c|c|c|c|c|}
\hline $\begin{array}{l}\text { Shell core } \\
\mathrm{Ni}-\mathrm{Mg} / \mathrm{Al}\end{array}$ & $\begin{array}{l}\text { Co-precipitation, then } \\
\text { wet impregnation and } \\
\text { finally calcination at } \\
700^{\circ} \mathrm{C} \text { for } 6 \mathrm{~h}\end{array}$ & $700^{\circ} \mathrm{C}$ & $\begin{array}{l}\text { Shell core catalyst exhibited } \\
\text { better hydrogen yield for per } \\
\text { mol of } \mathrm{Ni} \text { atoms than the } \\
\text { conventional } \mathrm{Ni}-\mathrm{Mg}-\mathrm{Al}-\mathrm{Htlc} \\
\text { catalyst }\end{array}$ & $\begin{array}{l}\text { Considerable deposition of } \\
\text { both encapsulating and } \\
\text { filaments } \\
\text { C species on the catalyst } \\
\text { surface }\end{array}$ & 75 & [146] \\
\hline $\mathrm{Ni}-\mathrm{Fe}-\mathrm{Htlc}$ & $\begin{array}{l}\text { Co-precipitation and } \\
\text { then calcination in } \\
\text { static air at } 500 \text { and } \\
800^{\circ} \mathrm{C} \text { for } 3 \mathrm{~h}\end{array}$ & $500^{\circ} \mathrm{C}$ & $\begin{array}{l}\text { Calcination temperature was } \\
\text { found to affect catalytic } \\
\text { performance and Fe presence in } \\
\text { the Ni-Htlc catalyst found to } \\
\text { increase catalytic activity and } \mathrm{H}_{2} \\
\text { selectivity }\end{array}$ & $\begin{array}{l}\text { High calcination } \\
\text { temperature }\left(800^{\circ} \mathrm{C}\right) \text { of the } \\
\text { catalyst caused higher } \\
\text { carbon deposition and } \mathrm{Ni}^{\circ} \\
\text { sintering during ethanol } \\
\text { steam reforming }\end{array}$ & 60 & [147] \\
\hline $\mathrm{Ni}-\mathrm{Fe} \mathrm{Htlc}$ & $\begin{array}{l}\text { Co-precipitation and } \\
\text { then calcination at } \\
500^{\circ} \mathrm{C} \text { for } 6 \mathrm{~h} \text { in static } \\
\text { air }\end{array}$ & $400^{\circ} \mathrm{C}-600^{\circ} \mathrm{C}$ & $\begin{array}{l}\text { Iron in Ni-based } \mathrm{Htlc} \text { catalyst } \\
\text { enhances activity and } \mathrm{h}_{2} \\
\text { selectivity by promoting } \mathrm{ni} \\
\text { dispersion and lowering } \mathrm{Ni}^{\circ} \\
\text { crystal size }\end{array}$ & $\begin{array}{l}\text { Excess iron in the catalyst } \\
\text { decreases activity }\end{array}$ & 60 & [148] \\
\hline $\begin{array}{l}\mathrm{Cu} \text { impregnated } \\
\mathrm{Mg}-\mathrm{Al}(\mathrm{Htlc})\end{array}$ & $\begin{array}{l}\text { Wet impregnation, } \\
\text { grinding and thermal } \\
\text { treatment at } 275^{\circ} \mathrm{C} \text { for } \\
24 \mathrm{~h}\end{array}$ & $200^{\circ} \mathrm{C}-600^{\circ} \mathrm{C}$ & $\begin{array}{l}\text { Improved } \mathrm{H}_{2} \text { production and } \\
\text { good stability during sorption } \\
\text { enhanced ethanol steam } \\
\text { reforming }\end{array}$ & $\begin{array}{l}\text { High CO content of around } \\
5000 \mathrm{ppm} \text { due to poor } \\
\text { catalytic activity for WGS } \\
\text { reaction during } \\
\text { pre-breakthrough periods }\end{array}$ & 90 & [149] \\
\hline Co-Mg/Al Htlc & $\begin{array}{l}\text { Co-precipitation } \\
\text { followed by calcination } \\
\text { at } 550^{\circ} \mathrm{C} \text { for } 3 \mathrm{~h}\end{array}$ & $\begin{array}{l}250^{\circ} \mathrm{C}-550^{\circ} \mathrm{C} \mathrm{\&} \\
\text { atmospheric } \\
\text { pressure }\end{array}$ & $\begin{array}{l}\text { Improved activity and selectivity } \\
\text { towards } \mathrm{H}_{2} \text { at moderate } \\
\text { temperature and } \\
\text { good stability even under higher } \\
\text { ethanol loadings }\end{array}$ & $\begin{array}{l}\text { The catalyst showed slow } \\
\text { deactivation over time }\end{array}$ & 65 & [143] \\
\hline $\begin{array}{l}\text { Htlc based } \\
\mathrm{Co}-\mathrm{Mg} / \mathrm{Al} \\
\mathrm{Rh}-\mathrm{Mg} / \mathrm{Al} \\
\text { \&RhCo-Mg/Al }\end{array}$ & $\begin{array}{l}\text { Co-precipitation and } \\
\text { then wet impregnation } \\
\text { for support (Rh \& Co) } \\
\text { and finally calcination } \\
\text { at } 800^{\circ} \mathrm{C} \text { for } 2 \mathrm{~h}\end{array}$ & $\begin{array}{l}500^{\circ} \mathrm{C} \& \\
\text { atmospheric } \\
\text { pressure }\end{array}$ & $\begin{array}{l}\mathrm{Mg} \text { - } \mathrm{Al} \mathrm{Htlc} \mathrm{based} \mathrm{catalyst} \\
\text { supported with both Rh and Co } \\
\text { showed high } \mathrm{H}_{2} \text { yield from EtOH } \\
\text { and low ethane selectivity }\end{array}$ & $\begin{array}{l}\mathrm{Mg} \text { containing catalysts } \\
\text { generated higher amounts } \\
\text { of } \mathrm{CH}_{4} \text { and } \mathrm{CO} \text { as } \\
\text { compared to } \\
\text { magnesium-free catalysts }\end{array}$ & 40 & [150] \\
\hline $\begin{array}{l}\text { Htlc derived } \\
\mathrm{Co}-\mathrm{Zn} / \mathrm{Al} \text {, } \\
\text { Co-Mg/Al, } \\
\text { Co- } \mathrm{Al}, \mathrm{Ni}-\mathrm{Mg} / \mathrm{Al} \\
\& \mathrm{Cu}-\mathrm{Mg} / \mathrm{Al}\end{array}$ & $\begin{array}{l}\text { Urea hydrolysis } \\
\text { followed by calcination } \\
\text { at } 450^{\circ} \mathrm{C} \text { for } 7 \mathrm{~h}\end{array}$ & $575^{\circ} \mathrm{C}-675^{\circ} \mathrm{C}$ & $\begin{array}{l}\text { Presence of } \mathrm{Zn} \text { increased the } \\
\text { reducibility of Co in the catalyst. } \\
\text { Thus, at } 575^{\circ} \mathrm{C} \mathrm{CoZnA} \text { was the } \\
\text { best catalyst for } \mathrm{H}_{2} \text { production }\end{array}$ & $\begin{array}{l}\text { CuMgAl exhibited low } \\
\text { catalytic activity and } \\
\text { selectivity to } \mathrm{H}_{2}\end{array}$ & 63.7 & [151] \\
\hline $\begin{array}{l}\text { Htlc derived } \\
\mathrm{Ni} / \mathrm{Zn}-\mathrm{Mg}-\mathrm{Al}\end{array}$ & $\begin{array}{l}\text { Co-precipitation and } \\
\text { calcination }\end{array}$ & $\begin{array}{l}700^{\circ} \mathrm{C} \& \\
\text { atmospheric } \\
\text { pressure }\end{array}$ & $\begin{array}{l}\text { Catalyst containing } \mathrm{Mg} / \mathrm{Zn} \text { ratio } \\
\text { of } 4 \text { exhibited improved } \\
\text { performance and impressive } \mathrm{H}_{2} \\
\text { yield of } 5.15 \mathrm{~mol} \text { per mol Et-OH } \\
\text { at } 700^{\circ} \mathrm{C}\end{array}$ & $\begin{array}{l}\text { Comparatively high coke } \\
\text { formation during EtOH } \\
\text { steam reforming }\end{array}$ & $\begin{array}{l}5.15 \\
\mathrm{~mol} / \mathrm{mol} \\
\mathrm{Et}-\mathrm{OH}\end{array}$ & [152] \\
\hline $\begin{array}{l}\text { Htlc derived } \\
\mathrm{Ni}-\mathrm{Co}-\mathrm{Zn}-\mathrm{Al}\end{array}$ & $\begin{array}{l}\text { Urea hydrolysis } \\
\text { followed by calcination } \\
\text { at } 700^{\circ} \mathrm{C} \text { for } 5 \mathrm{~h}\end{array}$ & $497^{\circ} \mathrm{C}-597^{\circ} \mathrm{C}$ & $\begin{array}{l}\text { At temperatures between } 447 \\
\text { and } 597^{\circ} \mathrm{C} \text { presence of Co } \\
\text { increased the selectivity of the } \\
\text { catalyst to } \mathrm{H}_{2} \text { and } \mathrm{CO}_{2} \text { and } \\
\text { decreased selectivity to } \mathrm{CH}_{4}\end{array}$ & $\begin{array}{l}\text { Catalytic performance } \\
\text { decreased at temperatures } \\
\text { higher than } 550^{\circ} \mathrm{C}\end{array}$ & 90 & [153] \\
\hline $\begin{array}{l}\text { La\&Ce promoted } \\
\text { hydrotalcite } \\
(\mathrm{Ni}-\mathrm{Mg} / \mathrm{Al})\end{array}$ & $\begin{array}{l}\text { Co-precipitation } \\
\text { followed by La and Ce } \\
\text { addition by anion } \\
\text { exchange and finally } \\
\text { calcination in air at } \\
500^{\circ} \mathrm{C} \text { for } 15 \mathrm{~h}\end{array}$ & $\begin{array}{l}550^{\circ} \mathrm{C} \& 650^{\circ} \mathrm{C} \\
\text { and atmospheric } \\
\text { pressure }\end{array}$ & $\begin{array}{l}\text { Incorporation of both } \mathrm{Ce} \text { and } \mathrm{La} \\
\text { in the catalyst }(\mathrm{Ni} / \mathrm{Mg} / \mathrm{Al}) \\
\text { improved } \mathrm{H}_{2} \text { yield and at } 650^{\circ} \mathrm{C} \\
\text { catalysts achieved near } 100 \% \\
\text { ethanol conversion }\end{array}$ & $\begin{array}{l}\text { Ethanol conversion } \\
\text { decreased at low } \\
\text { temperature }\end{array}$ & 75 & [154] \\
\hline
\end{tabular}


Cerda-Moreno et al., [32] synthesized Zinc-hydrotalcite (Zn-HT) catalyst containing different amounts of cobalt (Co) via co-precipitation method and subjected the catalysts to ethanol steam reforming. They found that $\mathrm{Zn}-\mathrm{HT}$ catalyst with $20 \mathrm{wt} \%$ Co exhibited the best result in the means of total ethanol conversion and high $\mathrm{H}_{2}$ yield. A high presence of reduced cobalt and small crystallite size of metallic cobalt in the $20 \%$ Co supported Zn-HT was found to be the cause behind the enhanced catalytic activity. Furthermore, 20\% Co supported Zn-HT catalyst with $1 \mathrm{wt} \%$ of lanthanum (La) improved catalytic stability. Thus, C. Cerda-Moreno and co-workers concluded that Co supported Zn-HT catalyst promoted with $\mathrm{La}$ is a potential catalyst for hydrogen production. Developed catalyst offers enhanced Et-OH conversion, good stability and, high $\mathrm{H}_{2}$ selectivity during Et-OH steam reforming. Munoz et al., [141] synthesized mixed oxide $\mathrm{NiCo}-\mathrm{MgAl}$ catalyst from HT precursor for oxidative steam reforming of ethanol. They utilized microwave or ultrasound-assisted co-precipitation method for catalyst development and found that microwave or ultrasound assistance reduced catalyst preparation time and improved both reducibility and basicity of the catalyst. However, ultrasound treatment caused surface defects and high basicity of the catalyst favored side reaction that might reduce $\mathrm{H}_{2}$ yield. Ultrasound-assisted co-precipitation method was also utilized by Espitia-Sibaja and co-workers [142] to prepare the $\mathrm{Co}-\mathrm{Mg} / \mathrm{Al}$ catalyst from HT-like precursor for oxidative ethanol steam reforming. The Co-Mg/Al catalyst with $10 \%$ to $15 \%$ Co content exhibited the best performance. Whereas, Co content less than $10 \%$ promoted the production of undesirable by-products and Co content more than $15 \%$ in the catalyst increased particle agglomeration. They also reported that the percentage of active Co phase has an effect on the properties and structure of the catalyst. Cobalt-5HT catalyst $(\mathrm{Co} / \mathrm{Mg} / \mathrm{Al}-\mathrm{Htlc})$ for Et-OH steam reforming was also evaluated by Espinal et al., [143]. They doped the (Co/Mg/Al-Htlc) in catalyst with potassium $(\mathrm{K})$ and used a catalytic membrane reactor for the Et-OH steam reforming and staged membrane reactor. Catalytic membrane reactor at $600^{\circ} \mathrm{C}$ temperature and 12 bar pressure showed 3 times higher $\mathrm{H}_{2}$ yield than staged membrane reactor. Thus, the researchers were able to demonstrate long term ethanol steam reforming at moderate temperatures using Co-HT catalyst. Besides, hydrotalcite derived $\mathrm{Ni}_{\mathrm{X}} \mathrm{Mg}_{2} \mathrm{AlO}_{\mathrm{Y}}$ catalyst was developed by Fang et al., [144] for the production of hydrogen from bio-ethanol. They studied the influence of $\mathrm{Ni}$ content in the performance of the $\mathrm{Ni}_{\mathrm{X}} \mathrm{Mg}_{2} \mathrm{AlO}_{\mathrm{Y}}$ catalyst. Ni content and $\mathrm{H}_{2}$ pretreatment of the catalyst were found to affect the catalytic performances. Their $\mathrm{Ni}_{\mathrm{X}} \mathrm{Mg}_{2} \mathrm{AlO}_{\mathrm{Y}}$ catalyst prepared via co-precipitation and thermal treatment method had particle size around $4 \mathrm{~nm}$ and showed high $\mathrm{H}_{2}$ yield with total Et-OH conversion.

Zeng et al., [145] explored a slightly different path, where they synthesized $\mathrm{La}-\mathrm{Ni}(\mathrm{Mg}-\mathrm{Al})$ from perovskite and hydrotalcite precursor for Et-OH steam reforming. The shell core type perovskite at $\mathrm{HT}$ catalyst exhibited high $\mathrm{H}_{2}$ yield, excellent catalytic activity, and improved stabilities during ethanol steam reforming. They mentioned that $\mathrm{LaNi}(\mathrm{Mg}, \mathrm{Al}) \mathrm{O}_{3}$ perovskite with shell-type con- 
figuration present in the catalyst could be linked to the enhanced performance of the catalyst. Zeng and co-workers [146] in another study evaluated the catalytic performance of shell-core $\mathrm{Ni}-\mathrm{Mg} / \mathrm{Al}$ catalyst derived from hydrotalcite type material for ethanol steam reforming. Comparing shell core $\mathrm{Ni}-\mathrm{Mg} / \mathrm{Al}$ catalyst with bulk Ni-Mg/Al catalyst the researchers found that shell core catalysts having lower nickel content exhibited improved $\mathrm{H}_{2}$ yield at $700^{\circ} \mathrm{C}$. On the other hand, Abelló et al., [147] studied Ni-Fe-HT catalyst for $\mathrm{H}_{2}$ production by Et-OH steam reforming. They synthesized Ni-Fe catalyst from hydrotalcite-like material (reevesite) and examined the effect of the calcination temperature and $\mathrm{Fe}$ content of the catalyst on the catalytic performances. According to their findings, catalyst calcined at $500^{\circ} \mathrm{C}$ with nickel/iron ratio of lexhibited the best catalytic performances. They concluded that Fe addition positively affects Ni-based HT catalysts by increasing $\mathrm{H}_{2}$ selectivity, improving $\mathrm{Ni}$ dispersion and decreasing carbon deposition. Ni-Fe-HT catalyst was also studied by Bolshak et al., [148] for Et-OH steam reforming. They found a similar result that, the catalyst containing $\mathrm{Ni} / \mathrm{Fe}$ ratio of 1:1 exhibited higher catalytic activities. However, they also mentioned that increasing temperature during Et-OH steam reforming with Ni-Fe-HT catalyst promoted ethanol dehydrogenation and decreased carbon deposition.

Cunha et al., [149] prepared $\mathrm{Cu}-\mathrm{Mg} / \mathrm{Al} \mathrm{HT}$ catalyst for sorption enhanced ethanol steam reforming by impregnating active copper particles to a commercial hydrotalcite compound containing magnesium and aluminum. The developed $\mathrm{Cu}-\mathrm{Mg}$-Al catalyst showed good stability and improved hydrogen production during sorption enhanced ethanol steam reforming. But, high CO content in the product stream due to limited catalytic activity for WGS reaction is a drawback of the catalyst. On the other hand, Espinal et al., [134] synthesized cobalt hydrotalcite (Co-Mg/Al-Htlc) catalyst for Et-OH steam reforming and observed that, $\mathrm{Co} / \mathrm{Mg} / \mathrm{Al}-\mathrm{Htlc}$ catalyst having Co:Mg:Al molar ratio of 1:2:1 exhibited the best catalytic performance and selectivity towers $\mathrm{H}_{2}$ at moderate temperatures. In situ experiments conducted by the researchers indicated that $\mathrm{Co}^{2+}$ species are beneficial for ethanol steam reforming and spinel $\mathrm{Co}-\mathrm{Al}$ and $\mathrm{CoO}$ particles interact with $\mathrm{MgO}$ strongly. Elsewhere, Moura et al., [150] conducted Et-OH steam reforming over $\mathrm{Rh}$ (rhodium) and/or Co (cobalt) promoted HT catalyst and examined the effect of the support on the catalytic activity. The catalytic performance evaluation was done in a fixed bed tubular quartz reactor containing $0.150 \mathrm{~g}$ catalyst under atmospheric pressure and $500^{\circ} \mathrm{C}$ temperature. Among the developed catalysts, $\mathrm{Mg}-\mathrm{Al} \mathrm{HT}$ catalyst containing both $\mathrm{Rh}$ and $\mathrm{Co}$ exhibited the best performance during Et-OH steam reforming with a $\mathrm{H}_{2}$ yield of $40 \%$ and selectivity of $57 \%$.

Hydrotalcite ( $\mathrm{Mg}-\mathrm{Al}$ ) based catalysts containing $\mathrm{Co}, \mathrm{Ni}$ and $\mathrm{Cu}$ were evaluated by Guil-Lo'pez et al., [151] for hydrogen production by oxidative $\mathrm{C}_{2} \mathrm{H}_{5} \mathrm{OH}$ steam reforming. They utilized the urea hydrolysis method for catalyst synthesis. Among the developed catalysts CoZnAl-HT showed the best catalytic performance $\left(\mathrm{H}_{2}\right.$ selectivity of $\left.85 \%\right)$ and $\mathrm{CuMgAl}-\mathrm{HT}$ appeared to have the lowest cat- 
alytic performance $\left(\mathrm{H}_{2}\right.$ selectivity of $\left.21 \%\right)$ at a lower temperature $\left(575^{\circ} \mathrm{C}\right)$. Their experiment revealed that Co catalysts have batter $\mathrm{H}_{2}$ selectivity and yield during oxidative ethanol steam reforming than $\mathrm{Ni}$ catalysts. Ni loaded $\mathrm{Mg}-\mathrm{Zn}-\mathrm{Al}$ catalyst prepared from hydrotalcite precursor via co-precipitation method was investigated by Zeng and co-workers [151] to study the synergy effect of $\mathrm{MgO}$ and $\mathrm{ZnO}$ during $\mathrm{C}_{2} \mathrm{H}_{5} \mathrm{OH}$ steam reforming for hydrogen production [152]. They found that at $700^{\circ} \mathrm{C} \mathrm{Ni-Mg-Zn-Al} \mathrm{Htlc} \mathrm{catalyst} \mathrm{with} \mathrm{Mg} / \mathrm{Zn}$ ratio of 4 showed excellent stability and high hydrogen yield. Busca et al., [153] synthesized a slightly different $\mathrm{Ni} / \mathrm{Co}-\mathrm{Zn}-\mathrm{Al}$ catalyst from hydrotalcite precursor via the urea hydrolysis process for $\mathrm{C}_{2} \mathrm{H}_{5} \mathrm{OH}$ steam reforming. With the developed $\mathrm{Ni}-\mathrm{Co}-\mathrm{Zn}-\mathrm{Al}$ catalyst Guido Busca and co-workers were able to achieve $90 \% \mathrm{H}_{2}$ yield at $540{ }^{\circ} \mathrm{C}$ and water to ethanol feed ratio of 6 . They mentioned that the reason behind the high selectivity of the catalyst to $\mathrm{H}_{2}$ might be related to the stability of partially reduced catalyst surface. Finally, Lucrédio et al., [154] evaluated the influence of lanthanum (La) and cerium (Ce) addition on the catalytic performance of HT type $\mathrm{Ni}-\mathrm{Mg} / \mathrm{Al}$ catalyst during Et-OH steam reforming. Their analysis revealed that, $\mathrm{Ni}$ as $\mathrm{NiO}$ strongly and La moderately interacts with the $\mathrm{Mg}$-Al support. But, Ce species has almost no interaction with the $\mathrm{Mg}$-Al support. Both $\mathrm{La}$ and Ce incorporation resulted in High Et-OH conversion, improved $\mathrm{H}_{2}$ production, and low carbon deposition. As mentioned by the researchers, the improved catalytic performance of $\mathrm{Ce}-\mathrm{Ni}-\mathrm{Mg}-\mathrm{Al}$ catalyst is linked to the less interaction of the support with Ce species, which increased $\mathrm{H}_{2} \mathrm{O}$ adsorption on $\mathrm{CeO}_{2}$ and thus helped ethanol and acetaldehyde conversions.

Hydrotalcite derived materials exhibited impressive catalytic performances in ethanol steam reforming. The hydrogen yield of HT based catalysts during ethanol steam reforming that are discussed in Table 4 is presented in Figure 3 below.

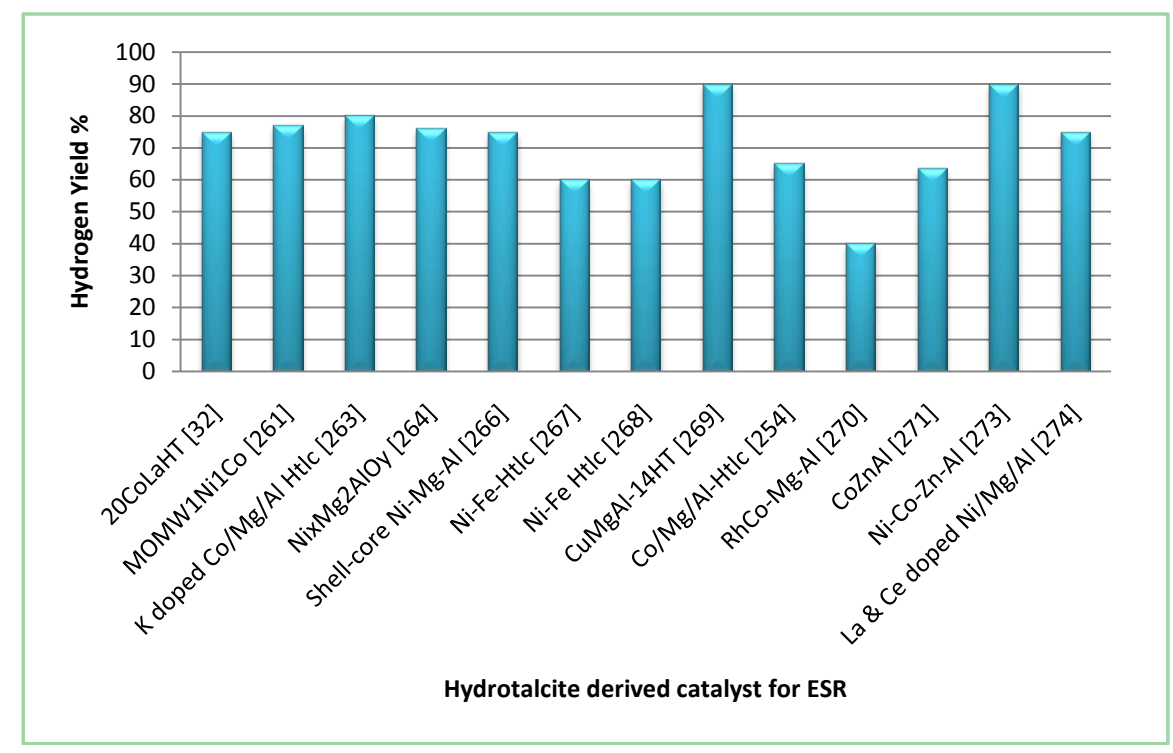

Figure 3. Performance of different Htlc based catalysts during ESR. 


\section{Discussion (Special Properties of Hydrotalcite Derived Catalyst to Reforming, Transesterification and Hydrogenation Reaction)}

Methane reforming to hydrogen depends on a couple of factors that indicate performances of the system. The system requires the presence of steam and high temperature. Due to the interaction between support and catalyst and high temperature causes of catalyst sintering and coke formation. Both cases are fundamental problems of catalyst deactivation. This carbonaceous deactivation of the catalyst is a major limitation of methane reforming to hydrogen. There are couple of studies that have been cited on the pros and cons of DRM and SMR where corresponds to deposition problems and their remedies. Other than catalyst deactivation, the optimum composition of feed gas and steam ratio, operating pressure and temperature are also very important. Catalytic activity, selectivity and stability of a catalyst depends on material structure, active site and surface morphology, molar ratios of the metals, preparation methods, incorporation of promoters and mainly the elements that acts as promoters [155]. As example, MSR has been widely investigated and demonstrated that $\mathrm{Cu} / \mathrm{ZnO} / \mathrm{Al}_{2} \mathrm{O}$ catalyst commonly used at $240^{\circ} \mathrm{C}-260^{\circ} \mathrm{C}$ [27] [39] [40]. Since, copper leading catalyst are very effective, low cost and it produces significant amount of carbon monoxide but shows less stable and pyrophoric nature. Conant et al., [41] showed catalyst deactivation using water molar fraction above the stoichiometric amount. Hydrotalcite derived $\mathrm{Ni} / \mathrm{Mg}-\mathrm{Al}$ or $\mathrm{Fe} / \mathrm{Mg}-\mathrm{Al}$ catalysts were mentioned to be highly active for $\mathrm{CO}_{2}$ reforming of $\mathrm{CH}_{4}$. They also observed that at higher temperature sintering of $\mathrm{Ni}$ particles increases and coke deposition decreases with higher Ni loadings in the catalyst. A less activation energy of the reaction is due to the catalyst performances that help to reform methane and prolong the deactivation of the catalyst. Activity, sulfur poisoning, carbon formation, sintering are four challenges of steam methane reforming [156]. Group VIII metals are active selection for the steam reforming of methane. Alkalis' make obstacle the activities of group VIII metals. The support should be able to withstand such conditions without losing strength [157]. For steam methane reforming, Ni containing hydrotalcite and calcium aluminates catalyst work best $(99 \%)$ at $550^{\circ} \mathrm{C}$ that can overcome the limitation of steam methane reforming with the special properties of hydrotalcite derived catalysts.

Superior MSR (Methanol steam reforming) catalyst should more active, stable and cause of producing less $\mathrm{CO}_{2}$ in the reforming system. Moreover, moderate temperature and pressure also desired. The performance of MSR is significantly dependent on the reforming catalyst. Copper-based and palladium-based catalysts for methanol steam reforming had studied well [158]. Several schemes have been proposed regarding the reaction mechanism of methanol steam reforming. The methanol steam reforming-methanol decomposition-reverse water gas shift reaction scheme is generally accepted for methanol steam reforming reactions occurring over the copper-based or palladium-based catalysts. Three reactions of the methanol decomposition, water gas shift reaction and methanol steam re- 
forming are assumed to occur in parallel. since, hydrotalcite derived catalysts are well stable, active surface that prolong the catalyst life and complete the all steps of reaction [159]. $\mathrm{Cu}$ (copper) supported $\mathrm{Zn}, \mathrm{Al}$-containing catalyst performs best $(99.98 \%)$ for steam reforming of methanol at $300^{\circ} \mathrm{C}$ whereas $\mathrm{Cu}$ impregnated $\mathrm{Mg}-\mathrm{Al}$ containing hydrotalcite is best (99\%) for steam reforming of ethanol at $200^{\circ} \mathrm{C}-600^{\circ} \mathrm{C}$. Dehydration and dehydrogenation are main two reaction path of steam reforming of ethanol. Carbon deposition occur via the Boudouard reaction that encapsulates carbon and blocks the active sites of the catalysts results in catalyst deactivation. A particular ethanol and water ratio oppose the carbon deposition. Hydrotalcite derived catalyst act as a relatively good carbondioxide sorbent at $400^{\circ} \mathrm{C}$.

The performance of transesterification process depends on mode of reaction, molar ratio of alcohol to oil, type of alcohol, reaction time, temperature and amount of catalyst. Catalyst one of the key parameters to influence the whole reforming process. Acid-catalyst transesterification and base catalyst transesterification are two best method of transesterification. Hydrotalcite derived catalyst can be designed into two both such as acid and base nature catalyst. The rate of transesterification is actively correlated with inter-layer electron density of HT. The conversion to methyl esters over the catalysts is in the following order: $\mathrm{KI} / \mathrm{Al}_{2} \mathrm{O}_{3}>\mathrm{KF} / \mathrm{Al}_{2} \mathrm{O}_{3}>\mathrm{KOH} / \mathrm{Al}_{2} \mathrm{O}_{3}>\mathrm{KNO}_{3} / \mathrm{Al}_{2} \mathrm{O}_{3}>\mathrm{K}_{2} \mathrm{CO}_{3} / \mathrm{Al}_{2} \mathrm{O}_{3}>$ $\mathrm{KBr} / \mathrm{Al}_{2} \mathrm{O}_{3} \cdot \mathrm{KI} / \mathrm{Al}_{2} \mathrm{O}_{3}$ demonstrated superior catalytic activity compared to the other catalysts [160]. The most favorable environment (99.99\%) for the transesterification of methanol is at $100^{\circ} \mathrm{C}-120^{\circ} \mathrm{C} \& 4.8-5.0$ atm over $\mathrm{Zr}$-doped $\mathrm{Mg}-\mathrm{Al}$ containing hydrotalcite, whereas $\mathrm{Ca}-\mathrm{Al} \mathrm{LDHs}$ best for transesterification of ethanol. The structure of the HT are very suitable to re-structure as required for better catalysis of the system.

Hydrogenation of ethyl acetate to ethanol shows plausible reaction pathway. The most probable cause of higher conversion of ethyl acetate is carbonyl activation that depends on the active sites of the metal in catalysts [161]. The weak acyl structure role is to desorbs resultant products from surface of the catalyst. Ethoxy group are formed through the cleavage of $\mathrm{C}-\mathrm{O}$ bond of the hemiacetal group and later hydrogenated to ethanol. There are some side products during the hydrogenation reaction. Hydrotalcite derived catalyst could be design considering to prevent the sight reactions, to have enough active sites, formation of the weak acyle structure. Some are very economic metals that ensure those properties in hydrotalcite derived catalyst and happen a better hydrogenation to ethanol. The hydrogenation process can be performed with even small amount of catalyst and in the presence of lower quantities or without solvent. $\mathrm{Y}_{2} \mathrm{O}_{3}$-modified $\mathrm{Cu} / \mathrm{ZnO} / \mathrm{Al}_{2} \mathrm{O}$ hydrotalcite performs best (89.7\%) for hydrogenation to different fuels at a temperature of $230^{\circ} \mathrm{C} \& 3-9$ atm.

Multi-component hydrotalcite is an excellent precursor for the preparation of potential mixed oxides with a homogenous distribution of metal [162]. Partial substitution of metal can be used to refine catalytic properties of the material. The anions and water are randomly placed in the interlayer and are loosely 
bounded. Suitable anion can be used as per the requirement of the functional system. The strength of the hydrogen bonding between anions and the hydroxyl groups of the layers, size and orientation influence to the thickness of the interlayer. Calcined hydrotalcite or mixed oxides are highly active and selective, and can play an important role in many catalyzed based reaction. Controlled thermal decomposition of hydrotalcite produced high specific surface area of mixed oxides that have various applications. Hydrotalcite show an important property "memory effect" by which the material recover its original layer structure if they contact with water. Regeneration of these materials can be done efficiently. Another important property of this material is acid-base pairs that can be created and offer active site for many reactions or gas adsorption. Added alkali solution with a fixed $\mathrm{pH}$ in such a rate as to maintain the $\mathrm{pH}$ at a certain range which help to careful control of charge density of $\left(\mathrm{M}^{(\mathrm{II})} / \mathrm{M}^{(\mathrm{III})}\right.$ ratio) of the hydroxide layers to co-precipitate of the two or more metallic salts [162]. These conditions give rise to precipitate higher crystalline particle than those obtained under high super saturation conditions due to the rate of the crystal growth is higher than the rate of nucleation.

Special physical \& chemical properties that hydrotalcite shows: 1) Homogenous distribution of metals, 2) Cations exchange materials, 3) High specific surface area and surface energy, 4) Tuneable surface morphology, 5) Cheap, Abundant and environment friendly, 6) High thermal stability make them very active catalyst especially as highly stable, less $\mathrm{CO}_{2}$ producing nano materials [163]. Due to the multi-layered materials, it can control water ratio and exchange electrons between homogeneously distributed metals on the surface and reforming agent that stipulated kinetics and thermodynamics.

The reaction environment generated by the hydrotalcite derived catalyst is most favorable for steam reforming, transesterification and hydrogenation is because of modification and design flexibility for the desired favorable catalytic activities, large surface area, basic properties, high amount homogeneous dispersion of metals, stability against sintering [164] [165].

\section{Conclusions}

The aforementioned literature review intends to present an overview of the latest advancement achieved by the researchers to develop hydrotalcite (HT) derived catalyst for hydrogen and bio-fuel production. Hydrotalcite has favorable properties such as memory effect, option to choose between different cations $\left(\mathrm{M}^{2+}\right.$ and $\mathrm{M}^{3+}$ ) and compositional ratios, basic properties and large surface area with an almost homogeneous distribution of active sites. This is why HT are favorable as catalyst precursors for different chemical processes. The comprehensive survey of literature articles reveals that the selectivity, catalytic performance, and stability of HT derived materials depend on structural property, chemical content, and phase composition. Factors like catalyst synthesis method, calcination, and reduction of catalyst, catalytic test conditions, the addition of promoters and 
the molar ratio of cations $\left(\mathrm{M}^{3+}, \mathrm{M}^{2+}\right.$, and/or promoter ions) in the catalyst affect to the catalytic efficiency. Especially, chemical composition (ratio of metallic components) and the interaction of the metal with hydrotalcite precursor have important roles in catalytic performances. Moreover, the promotion of HT precursor with metals like $\mathrm{Zr}, \mathrm{Ce}, \mathrm{Ni}, \mathrm{Co}$, Rh has the potentiality to improve the selectivity, stability, catalytic activity, and product yield as mentioned by various investigations. However, catalyst deactivation due to sintering of active metal ions and coke formation in the catalyst surface after application for a certain period of time has been reported widely. Efforts have been made to overcome the disadvantage by utilizing a modified catalyst synthesis method, pre-treatment and incorporation of metals such as $\mathrm{Ru}, \mathrm{Pt}, \mathrm{Cu}$, and $\mathrm{Ti}$, etc. But, agreement on a reliable method that may ensure good catalytic stability has not been found.

HT derived materials as fuel processing catalyst has received impressive progress. According to the literature reviewed above researchers were able to synthesize HT based mix oxide catalyst with improved catalytic activity and those catalysts were viable for industrial use. However, to achieve the desired stability with excellent catalytic activity from HT derived catalysts, there are several areas need to provide much attention. Most of the published scholarly articles on the catalytic performance of HT based catalyst deal with one or two active components. But, comprehensive studies about synergic interactions between different active components present in the catalytic system and their effect on activity are hardly found. Generally, HT derived catalysts are used in fixed bed reactors. HT based catalysts might be used in fluidized bed reactors by manipulating the physical properties. This will give the option to add continuous catalyst regeneration to unite in the system. Few conventional metallic promoters to enhance the performance of HT catalysts have been investigated. A wide variety of other inorganic and organic compounds should be studied to evaluate their promotional effect on HT derived catalysts.

\section{Declaration of Interests}

The authors declare that they have no known competing financial interests or personal relationships that could have appeared to influence the work reported in this paper.

\section{Acknowledgements}

We greatly appreciate the financial support by the annual development project, Ministry of science and technology, Bangladesh (Project Code. 1265-244250200), and the Strategic Priority Research Program of the BCSIR (Bangladesh Council of Scientific \& Industrial Research (BCSIR).

\section{Conflicts of Interest}

The authors declare no conflicts of interest regarding the publication of this paper. 


\section{References}

[1] Asif, M. and Muneer, T. (2007) Energy Supply, Its Demand and Security Issues for Developed and Emerging Economies. Renewable and Sustainable Energy Reviews, 11, 1388-1413. https://doi.org/10.1016/j.rser.2005.12.004

[2] Lu, Y., Zhang, Z., Xu, Y., Liu, Q. and Qian, G. (2015) CaFeAl Mixed Oxide Derived Heterogeneous Catalysts for Transesterification of Soybean Oil to Biodiesel. Bioresource Technology, 190, 438-441. https://doi.org/10.1016/j.biortech.2015.02.046

[3] Doyle, A.M., Albayati, T.M., Abbas, A.S. and Alismaeel, Z.T. (2016) Biodiesel Production by Esterification of Oleic Acid over Zeolite Y Prepared from Kaolin. Renewable Energy, 97, 19-23. https://doi.org/10.1016/j.renene.2016.05.067

[4] Oumer, A., Hasan, M., Baheta, A.T., Mamat, R. and Abdullah, A. (2018) Bio-Based Liquid Fuels as a Source of Renewable Energy: A Review. Renewable and Sustainable Energy Reviews, 88, 82-98. https://doi.org/10.1016/j.rser.2018.02.022

[5] Abidin, S.N.Z., Lee, H.V., Juan, J.C., Rahman, N.A. and Taufiq-Yap, Y.H. (2019) Production of Green Biofuel by Using a Goat Manure Supported Ni-Al Hydrotalcite Catalysed Deoxygenation Process. RSC Advances, 9, 1642-1652. https://doi.org/10.1039/C8RA07818A

[6] Shafiei, E., Davidsdottir, B., Leaver, J., Stefansson, H. and Asgeirsson, E.I. (2015) Comparative Analysis of Hydrogen, Biofuels and Electricity Transitional Pathways to Sustainable Transport in a Renewable-Based Energy System. Energy, 83, 614-627. https://doi.org/10.1016/j.energy.2015.02.071

[7] Li, S., Zheng, H., Zheng, Y., Tian, J., Jing, T., Chang, J.-S., et al. (2019) Recent Advances in Hydrogen Production by Thermo-Catalytic Conversion of Biomass. International Journal of Hydrogen Energy, 44, 14266-14278. https://doi.org/10.1016/j.ijhydene.2019.03.018

[8] Du, Y.-L., Wu, X., Cheng, Q., Huang, Y.-L. and Huang, W. (2017) Development of Ni-Based Catalysts Derived from Hydrotalcite-Like Compounds Precursors for Synthesis Gas Production via Methane or Ethanol Reforming. Catalysts, 7, 70. https://doi.org/10.3390/catal7020070

[9] Suelves, I., Lázaro, M., Moliner, R., Corbella, B. and Palacios, J. (2005) Hydrogen Production by Thermo Catalytic Decomposition of Methane on Ni-Based Catalysts: Influence of Operating Conditions on Catalyst Deactivation and Carbon Characteristics. International Journal of Hydrogen Energy, 30, 1555-1567.

https://doi.org/10.1016/j.ijhydene.2004.10.006

[10] Nuernberg, G.B., Fajardo, H.V., Mezalira, D.Z., Casarin, T.J., Probst, L.F. and Carreño, N.L. (2008) Preparation and Evaluation of $\mathrm{Co} / \mathrm{Al}_{2} \mathrm{O}_{3}$ Catalysts in the Production of Hydrogen from Thermo-Catalytic Decomposition of Methane: Influence of Operating Conditions on Catalyst Performance. Fuel, 87, 1698-1704.

https://doi.org/10.1016/j.fuel.2007.08.005

[11] Anis, S., Zainal, Z. and Bakar, M. (2013) Thermocatalytic Treatment of Biomass Tar Model Compounds via Radio Frequency. Bioresource Technology, 136, 117-125. https://doi.org/10.1016/j.biortech.2013.02.049

[12] Levin, D.B. and Chahine, R. (2010) Challenges for Renewable Hydrogen Production from Biomass. International Journal of Hydrogen Energy, 35, 4962-4969. https://doi.org/10.1016/j.ijhydene.2009.08.067

[13] Schmitt, N., Apfelbacher, A., Jäger, N., Daschner, R., Stenzel, F. and Hornung, A. (2019) Thermo-Chemical Conversion of Biomass and Upgrading to Biofuel: The Thermo-Catalytic Reforming Process-A Review. Biofuels, Bioproducts and Biorefining, 13, 822-837. https://doi.org/10.1002/bbb.1980 
[14] Li, P., He, C., Cheng, J., Ma, C.Y., Dou, B.J. and Hao, Z.P. (2011) Catalytic Oxidation of Toluene over Pd/Co3AlO Catalysts Derived from Hydrotalcite-Like Compounds: Effects of Preparation Methods. Applied Catalysis B: Environmental, 101, 570-579. https://doi.org/10.1016/j.apcatb.2010.10.030

[15] Olszówka, J., Karcz, R., Michalik-Zym, A., Napruszewska, B., Bielańska, E., Kryściak-Czerwenka, J., et al. (2019) Effect of Grinding on the Physico-Chemical Properties of $\mathrm{Mg}$-Al Hydrotalcite and Its Performance as a Catalyst for Baeyer-Villiger Oxidation of Cyclohexanone. Catalysis Today, 333, 147-153. https://doi.org/10.1016/j.cattod.2018.05.035

[16] Yi, H., Zhao, S., Tang, X., Ning, P., Wang, H. and He, D. (2011) Influence of Calcination Temperature on the Hydrolysis of Carbonyl Sulfide over Hydrotalcite-Derived Zn-Ni-Al Catalyst. Catalysis Communications, 12, 1492-1495. https://doi.org/10.1016/j.catcom.2011.05.034

[17] Shen, J., Tu, M. and Hu, C. (1998) Structural and Surface Acid/Base Properties of Hydrotalcite-Derived MgAlO Oxides Calcined at Varying Temperatures. Journal of Solid State Chemistry, 137, 295-301. https://doi.org/10.1006/jssc.1997.7739

[18] Basąg, S., Kovanda, F., Piwowarska, Z., Kowalczyk, A., Pamin, K. and Chmielarz, L. (2017) Hydrotalcite-Derived Co-Containing Mixed Metal Oxide Catalysts for Methanol Incineration. Journal of Thermal Analysis and Calorimetry, 129, 1301-1311. https://doi.org/10.1007/s10973-017-6348-7

[19] Liu, Y., Lotero, E., Goodwin Jr., J.G. and Mo, X. (2007) Transesterification of Poultry Fat with Methanol Using Mg-Al Hydrotalcite Derived Catalysts. Applied Catalysis A: General, 331, 138-148. https://doi.org/10.1016/j.apcata.2007.07.038

[20] Chmielarz, L., Kuśtrowski, P., Rafalska-Łasocha, A., Majda, D. and Dziembaj, R. (2002) Catalytic Activity of Co-Mg-Al, Cu-Mg-Al and Cu-Co-Mg-Al Mixed Oxides Derived from Hydrotalcites in SCR of NO with Ammonia. Applied Catalysis B: Environmental, 35, 195-210. https://doi.org/10.1016/S0926-3373(01)00254-5

[21] Álvarez, M., Chimentão, R., Figueras, F. and Medina, F. (2012) Tunable Basic and Textural Properties of Hydrotalcite Derived Materials for Transesterification of Glycerol. Applied Clay Science, 58, 16-24. https://doi.org/10.1016/j.clay.2012.02.004

[22] Silva, J.M., Trujillano, R., Rives, V., Soria, M.A. and Madeira, L.M. (2019) Dynamic Behaviour of a K-Doped Ga Substituted and Microwave Aged Hydrotalcite-Derived Mixed Oxide during $\mathrm{CO}_{2}$ Sorption Experiments. Journal of Industrial and Engineering Chemistry, 72, 491-503. https://doi.org/10.1016/j.jiec.2019.01.005

[23] Wang, X., Zhen, T. and Yu, C. (2016) Application of Ni-Al-Hydrotalcite-Derived Catalyst Modified with $\mathrm{Fe}$ or $\mathrm{Mg}$ in $\mathrm{CO}_{2}$ Methanation. Applied Petrochemical Research, 6, 217-223. https://doi.org/10.1007/s13203-016-0154-1

[24] Pan, G., Ni, Z., Cao, F. and Li, X. (2012) Hydrogen Production from Aqueous-Phase Reforming of Ethylene Glycol over Ni/Sn/Al Hydrotalcite Derived Catalysts. $A p$ plied Clay Science, 58, 108-113. https://doi.org/10.1016/j.clay.2012.01.023

[25] Pan, G., Ni, Z., Cao, F. and Li, X. (2010) Activation Mechanism and Hydrogen Production Performance of in Situ Reduction of Ni-Mg-Al Layered Double Hydroxides. Journal of the Chinese Ceramic Society, 38, 1328-1332. http://en.cnki.com.cn/Article en/CJFDTotal-GXYB201007033.htm

[26] Pan, G.X., Cao, F., Ni, Z.M., Li, X.N., Chen, H.F., Tang, P.S. and Xu, M.H. (2011) Preparation of NiMgAl Layered Double Hydroxides and Hydrogen Production from Aqueous-Phase Reforming of Ethylene Glycol. Journal of the Chinese Ceramic Society, 39, 585-589.

https://www.ingentaconnect.com/content/ccs/jccs/2011/00000039/00000004/art00007 
[27] Veiga, P.M., Sousa, Z.S., Polato, C., Portilho, M.F., Veloso, C.O. and Henriques, C.A. (2013) Influence of the Incorporation of Transition Metals on the Basicity of Mg, Al-Mixed Oxides and on Their Catalytic Properties for Transesterification of Vegetable Oils. Journal of Catalysts, 2013, Article ID: 685063. https://doi.org/10.1155/2013/685063

[28] Xie, X., Zhou, Q., Hu, X., Jia, X. and Huang, L. (2019) Zn-Al Hydrotalcite-Derived $\mathrm{Co}_{\mathrm{x}} \mathrm{Zn}_{\mathrm{y}} \mathrm{AlO}_{\mathrm{z}}$ Catalysts for Hydrogen Generation by Auto-Thermal Reforming of Acetic Acid. International Journal of Energy Research, 43, 7075-7084.

[29] Siano, D., Nastasi, M., Santacesaria, E., Di Serio, M., Tesser, R., Minutillo, G., et al. (2006) Process for Producing Esters from Vegetable Oils or Animal Fats Using Heterogeneous Catalysts. PCT Application No. WO2006/050925.

https://patents.google.com/patent/WO2006050925A1/zh

[30] Yu, Z., Chen, D., Rønning, M., Tøtdal, B., Vrålstad, T., Ochoa-Fernández, E., et al. (2008) Large-Scale Synthesis of Carbon Nanofibers on Ni-Fe-Al Hydrotalcite Derived Catalysts: II: Effect of Ni/Fe Composition on CNF Synthesis from Ethylene and Carbon Monoxide. Applied Catalysis A: General, 338, 147-158.

https://doi.org/10.1016/j.apcata.2008.01.002

[31] Li, D., Lu, M., Aragaki, K., Koike, M., Nakagawa, Y. and Tomishige, K. (2016) Characterization and Catalytic Performance of Hydrotalcite-Derived Ni-Cu Alloy Nanoparticles Catalysts for Steam Reforming of 1-Methylnaphthalene. Applied Catalysis B: Environmental, 192, 171-181.

https://doi.org/10.1016/j.apcatb.2016.03.052

[32] Cerdá-Moreno, C., Da Costa-Serra, J. and Chica, A. (2019) Co and La Supported on Zn-Hydrotalcite-Derived Material as Efficient Catalyst for Ethanol Steam Reforming. International Journal of Hydrogen Energy, 44, 12685-12692. https://doi.org/10.1016/j.ijhydene.2019.01.156

[33] Liu, Y., He, Y., Zhou, D., Feng, J. and Li, D. (2016) Catalytic Performance of Pd-Promoted Cu Hydrotalcite-Derived Catalysts in Partial Hydrogenation of Acetylene: Effect of Pd-Cu Alloy Formation. Catalysis Science \& Technology, 6, 3027-3037. https://doi.org/10.1039/C5CY01516B

[34] Daza, C.E., Gallego, J., Mondragón, F., Moreno, S. and Molina, R. (2010) High Stability of Ce-Promoted $\mathrm{Ni} / \mathrm{Mg}-\mathrm{Al}$ Catalysts Derived from Hydrotalcites in Dry Reforming of Methane. Fuel, 89, 592-603. https://doi.org/10.1016/j.fuel.2009.10.010

[35] Li, Q., Meng, M., Tsubaki, N., Li, X., Li, Z., Xie, Y., et al. (2009) Performance of K-Promoted Hydrotalcite-Derived CoMgAlO Catalysts Used for Soot Combustion, $\mathrm{NO}_{\mathrm{x}}$ Storage and Simultaneous Soot-NO $\mathrm{N}_{\mathrm{x}}$ Removal. Applied Catalysis B: Environmental, 91, 406-415. https://doi.org/10.1016/j.apcatb.2009.06.007

[36] Zhou, F., Pan, N., Chen, H., Xu, X., Wang, C., Du, Y., et al. (2019) Hydrogen Production through Steam Reforming of Toluene over $\mathrm{Ce}, \mathrm{Zr}$ or $\mathrm{Fe}$ Promoted $\mathrm{Ni}-\mathrm{Mg}$-Al Hydrotalcite-Derived Catalysts at Low Temperature. Energy Conversion and Management, 196, 677-687. https://doi.org/10.1016/j.enconman.2019.06.047

[37] Marocco, P., Morosanu, E.A., Giglio, E., Ferrero, D., Mebrahtu, C., Lanzini, A., et al. (2018) $\mathrm{CO}_{2}$ Methanation over Ni/Al Hydrotalcite-Derived Catalyst: Experimental Characterization and Kinetic Study. Fuel, 225, 230-242.

https://doi.org/10.1016/j.fuel.2018.03.137

[38] Wierzbicki, D., Motak, M., Grzybek, T., Gálvez, M.E. and Da Costa, P. (2018) The Influence of Lanthanum Incorporation Method on the Performance of Nickel-Containing Hydrotalcite-Derived Catalysts in $\mathrm{CO}_{2}$ Methanation Reaction. Catalysis Today, 307, 205-211. https://doi.org/10.1016/j.cattod.2017.04.020 
[39] De Lima, A.L. and Mota, C.J. (2019) Biodiesel: A Survey on Production Methods and Catalysts. In: Mulpuri, S., Carels, N. and Bahadur, B., Eds., Jatropha, Challenges for a New Energy Crop, Springer, Singapore, 475-491. https://doi.org/10.1007/978-981-13-3104-6 23

[40] Zhang, C.-Y., Shao, W.-L., Zhou, W.-X., Liu, Y., Han, Y.-Y., Zheng, Y., et al. (2019) Biodiesel Production by Esterification Reaction on $\mathrm{K}^{+}$Modified MgAl-Hydrotalcites Catalysts. Catalysts, 9, 742. https://doi.org/10.3390/catal9090742

[41] Lari, G.M., de Moura, A.B., Weimann, L., Mitchell, S., Mondelli, C. and Pérez-Ramírez, J. (2017) Design of a Technical Mg-Al Mixed Oxide Catalyst for the Continuous Manufacture of Glycerol Carbonate. Journal of Materials Chemistry A, 5, 16200-16211. https://doi.org/10.1039/C7TA02061A

[42] Benito, P., Vaccari, A., Antonetti, C., Licursi, D., Schiarioli, N., Rodriguez-Castellón, E., et al. (2019) Tunable Copper-Hydrotalcite Derived Mixed Oxides for Sustainable Ethanol Condensation to $n$-Butanol in Liquid Phase. Journal of Cleaner Production, 209, 1614-1623. https://doi.org/10.1016/j.jclepro.2018.11.150

[43] Basu, S. and Pradhan, N.C. (2020) Steam Reforming of Acetone over NiCoMgAl Mixed Oxide Catalysts Obtained from Hydrotalcite Precursors. International Journal of Hydrogen Energy, 45, 18133-18143. https://doi.org/10.1016/j.ijhydene.2019.04.173

[44] Siqueira, M.R., Perrone, O.M., Metzker, G., de Oliveira Lisboa, D.C., Thoméo, J.C. and Boscolo, M. (2019) Highly Selective 1-Butanol Obtained from Ethanol Catalyzed by Mixed Metal Oxides: Reaction Optimization and Catalyst Structure Behavior. Molecular Catalysis, 476, Article ID: 110516. https://doi.org/10.1016/j.mcat.2019.110516

[45] Lima-Corrêa, R.A., Castro, C.S., Damasceno, A.S. and Assaf, J.M. (2020) The Enhanced Activity of Base Metal Modified MgAl Mixed Oxides from Sol-Gel Hydrotalcite for Ethylic Transesterification. Renewable Energy, 146, 1984-1990. https://doi.org/10.1016/j.renene.2019.08.047

[46] Carvalho, D.C., Ferreira, N.A., Josué Filho, M., Ferreira, O.P., Soares, J.M. and Oliveira, A.C. (2015) Ni-Fe and Co-Fe Binary Oxides Derived from Layered Double Hydroxides and Their Catalytic Evaluation for Hydrogen Production. Catalysis Today, 250, 155-165. https://doi.org/10.1016/j.cattod.2014.08.010

[47] García-Sancho, C., Guil-López, R., Sebastián-López, A., Navarro, R. and Fierro, J. (2018) Hydrogen Production by Methane Decomposition: A Comparative Study of Supported and Bulk ex-Hydrotalcite Mixed Oxide Catalysts with $\mathrm{Ni}, \mathrm{Mg}$ and $\mathrm{Al}$. International Journal of Hydrogen Energy, 43, 9607-9621. https://doi.org/10.1016/j.ijhydene.2018.04.021

[48] Awad, A., Masiran, N., Salam, M.A., Vo, D.-V.N. and Abdullah, B. (2019) Non-Oxidative Decomposition of Methane/Methanol Mixture over Mesoporous $\mathrm{Ni}-\mathrm{Cu} / \mathrm{Al}_{2} \mathrm{O}_{3} \mathrm{Co}$-Doped Catalysts. International Journal of Hydrogen Energy, 44, 20889-20899. https://doi.org/10.1016/j.ijhydene.2018.04.233

[49] Gennequin, C., Tidahy, H.L., Aboukaïs, A., Abi-Aad, E., Tanios, C. and Labaki, M. (2019) Evaluation of a Catalyst Durability in Absence and Presence of Toluene Impurity: Case of the Material $\mathrm{Co}_{2} \mathrm{Ni}_{2} \mathrm{Mg}_{2} \mathrm{Al}_{2}$ Mixed Oxide Prepared by Hydrotalcite Route in Methane Dry Reforming to Produce Energy. Materials, 12, 1362. https://doi.org/10.3390/ma12091362

[50] Venugopal, A., Kumar, S.N., Ashok, J., Prasad, D.H., Kumari, V.D., Prasad, K., et al. (2007) Hydrogen Production by Catalytic Decomposition of Methane over $\mathrm{Ni} / \mathrm{SiO}_{2}$. International Journal of Hydrogen Energy, 32, 1782-1788.

https://doi.org/10.1016/j.ijhydene.2007.01.007 
[51] Saraswat, S.K. and Pant, K. (2011) Ni-Cu-Zn/MCM-22 Catalysts for Simultaneous Production of Hydrogen and Multiwall Carbon Nanotubes via Thermo-Catalytic Decomposition of Methane. International Journal of Hydrogen Energy, 36, 13352-13360. https://doi.org/10.1016/j.ijhydene.2011.07.102

[52] Saraswat, S.K. and Pant, K. (2013) Synthesis of Carbon Nanotubes by Thermo Catalytic Decomposition of Methane over Cu and Zn Promoted Ni/MCM-22 Catalyst. Journal of Environmental Chemical Engineering, 1, 746-754. https://doi.org/10.1016/j.jece.2013.07.009

[53] Bayat, N., Meshkani, F. and Rezaei, M. (2016) Thermocatalytic Decomposition of Methane to $\mathrm{CO}_{x}$-Free Hydrogen and Carbon over Ni-Fe-Cu/ $\mathrm{Al}_{2} \mathrm{O}_{3}$ Catalysts. International Journal of Hydrogen Energy, 41, 13039-13049.

https://doi.org/10.1016/j.ijhydene.2016.05.230

[54] Kung, H.H. and Ko, E.I. (1996) Preparation of Oxide Catalysts and Catalyst Supports-A Review of Recent Advances. The Chemical Engineering Journal and the Biochemical Engineering Journal, 64, 203-214. https://doi.org/10.1016/S0923-0467(96)03139-9

[55] Cavani, F., Trifiro, F. and Vaccari, A. (1991) Hydrotalcite-Type Anionic Clays: Preparation, Properties and Applications. Catalysis Today, 11, 173-301. https://doi.org/10.1016/0920-5861(91)80068-K

[56] De Roy, A., Forano, C., El Malki, K. and Besse, J.-P. (1992) Anionic Clays: Trends in Pillaring Chemistry. In: Occelli, M.L. and Robson, H.E., Eds., Expanded Clays and Other Microporous Solids, Springer, Boston, MA, 108-169. https://doi.org/10.1007/978-1-4684-8866-1_7

[57] Trifiro, F. and Vaccari, A. (1996) Comprehensive Supramolecular Chemistry. In: Atwood, J.L., Davies, J.D., MacNicol, D.D., Vögtle, F., Lehn, J.-M., Alberti, G. and Bein, T., Eds., Solid-State Supramolecular Chemistry: Two- and Three-Dimensional Inorganic Networks, Vol. 7, Pergamon-Elsevier Sci. Ltd., Oxford, 251.

[58] Vaccari, A. (1998) Preparation and Catalytic Properties of Cationic and Anionic Clays. Catalysis Today, 41, 53-71. https://doi.org/10.1016/S0920-5861(98)00038-8

[59] Rives, V. and Ulibarri, M.A. (1999) Layered Double Hydroxides (LDH) Intercalated with Metal Coordination Compounds and Oxometalates. Coordination Chemistry Reviews, 181, 61-120. https://doi.org/10.1016/S0010-8545(98)00216-1

[60] Kagunya, W., Hassan, Z. and Jones, W. (1996) Catalytic Properties of Layered Double Hydroxides and Their Calcined Derivatives. Inorganic Chemistry, 35, 5970-5974. https://doi.org/10.1021/ic960047e

[61] Debecker, D.P., Gaigneaux, E.M. and Busca, G. (2009) Exploring, Tuning, and Exploiting the Basicity of Hydrotalcites for Applications in Heterogeneous Catalysis. Chemistry: A European Journal, 15, 3920-3935.

https://doi.org/10.1002/chem.200900060

[62] Muhammad, A.F.S., Awad, A., Saidur, R., Masiran, N., Salam, A. and Abdullah, B. (2018) Recent Advances in Cleaner Hydrogen Productions via Thermo-Catalytic Decomposition of Methane: Admixture with Hydrocarbon. International Journal of Hydrogen Energy, 43, 18713-18734. https://doi.org/10.1016/j.ijhydene.2018.08.091

[63] Atadashi, I., Aroua, M., Aziz, A.A. and Sulaiman, N. (2013) The Effects of Catalysts in Biodiesel Production: A Review. Journal of Industrial and Engineering Chemistry, 19, 14-26. https://doi.org/10.1016/j.jiec.2012.07.009

[64] Pamatz-Bolaños, T., Cabrera-Munguia, D.A., González, H., Del Río, R.E., Rico, J.L., Rodríguez-García, G., et al. (2018) Transesterification of Caesalpinia eriostachys 
Seed Oil Using Heterogeneous and Homogeneous Basic Catalysts. International Journal of Green Energy, 15, 465-472. https://doi.org/10.1080/15435075.2018.1473775

[65] Silva, C.C.C., Ribeiro, N.F., Souza, M.M. and Aranda, D.A. (2010) Biodiesel Production from Soybean Oil and Methanol Using Hydrotalcites as Catalyst. Fuel Processing Technology, 91, 205-210. https://doi.org/10.1016/j.fuproc.2009.09.019

[66] Dias, J.M., Alvim-Ferraz, M.C. and Almeida, M.F. (2008) Comparison of the Performance of Different Homogeneous Alkali Catalysts during Transesterification of Waste and Virgin Oils and Evaluation of Biodiesel Quality. Fuel, 87, 3572-3578.

https://doi.org/10.1016/j.fuel.2008.06.014

[67] Demirbas, A. (2008) Biodiesel from Vegetable Oils with MgO Catalytic Transesterification in Supercritical Methanol. Energy Sources, Part A, 30, 1645-1651. https://doi.org/10.1080/15567030701268401

[68] Georgogianni, K., Katsoulidis, A., Pomonis, P. and Kontominas, M. (2009) Transesterification of Soybean Frying Oil to Biodiesel Using Heterogeneous Catalysts. Fuel Processing Technology, 90, 671-676. https://doi.org/10.1016/j.fuproc.2008.12.004

[69] Li, E., Xu, Z.P. and Rudolph, V. (2009) MgCoAl-LDH Derived Heterogeneous Catalysts for the Ethanol Transesterification of Canola Oil to Biodiesel. Applied Catalysis B: Environmental, 88, 42-49. https://doi.org/10.1016/j.apcatb.2008.09.022

[70] Zeng, H.-Y., et al. (2008) Activation of Mg-Al Hydrotalcite Catalysts for Transesterification of Rape Oil. Fuel, 87, 3071-3076. https://doi.org/10.1016/j.fuel.2008.04.001

[71] Sikander, U., Samsudin, M.F., Sufian, S., KuShaari, K., Kait, C.F., Naqvi, S.R., et al. (2019) Tailored Hydrotalcite-Based Mg-Ni-Al Catalyst for Hydrogen Production via Methane Decomposition: Effect of Nickel Concentration and Spinel-Like Structures. International Journal of Hydrogen Energy, 44, 14424-14433. https://doi.org/10.1016/j.ijhydene.2018.10.224

[72] Kou, J.-W., Cheng, S.-Y. and Bai, J.-L. (2019) Effects of Amino Trimethylene Phosphonic Acid on Structure and Properties of $\mathrm{Cu}-\mathrm{Zn}$-Al Hydrotalcite-Derived Oxides for Catalytic Synthesis of Iso-Butanol and Ethanol from Synthesis Gas. Fuel, 255, Article ID: 115833. https://doi.org/10.1016/j.fuel.2019.115833

[73] Jiang, Z., Kong, L., Chu, Z., France, L.J., Xiao, T. and Edwards, P.P. (2012) Catalytic Combustion of Propane over Mixed Oxides Derived from $\mathrm{Cu}_{\mathrm{x}} \mathrm{Mg}_{3-\mathrm{x}} \mathrm{Al}$ Hydrotalcites. Fuel, 96, 257-263. https://doi.org/10.1016/j.fuel.2011.11.027

[74] Di Serio, M., Mallardo, S., Carotenuto, G., Tesser, R. and Santacesaria, E. (2012) $\mathrm{Mg} / \mathrm{Al}$ Hydrotalcite Catalyst for Biodiesel Production in Continuous Packed Bed Reactors. Catalysis Today, 195, 54-58. https://doi.org/10.1016/j.cattod.2012.01.013

[75] Frontera, P., Macario, A., Ferraro, M. and Antonucci, P. (2017) Supported Catalysts for $\mathrm{CO}_{2}$ Methanation: A Review. Catalysts, 7, 59. https://doi.org/10.3390/catal7020059

[76] Tariq, M., Ali, S. and Khalid, N. (2012) Activity of Homogeneous and Heterogeneous Catalysts, Spectroscopic and Chromatographic Characterization of Biodiesel: A Review. Renewable and Sustainable Energy Reviews, 16, 6303-6316. https://doi.org/10.1016/j.rser.2012.07.005

[77] Wang, H., Blaylock, D.W., Dam, A.H., Liland, S.E., Rout, K.R., Zhu, Y.-A., et al. (2017) Steam Methane Reforming on a Ni-Based Bimetallic Catalyst: Density Functional Theory and Experimental Studies of the Catalytic Consequence of Surface Alloying of Ni with Ag. Catalysis Science \& Technology, 7, 1713-1725. https://doi.org/10.1039/C7CY00101K 
[78] Dębek, R., Galvez, M.E., Launay, F., Motak, M., Grzybek, T. and Da Costa, P. (2016) Low Temperature Dry Methane Reforming over Ce, $\mathrm{Zr}$ and CeZr Promoted Ni-Mg-Al Hydrotalcite-Derived Catalysts. International Journal of Hydrogen Energy, 41, 11616-11623. https://doi.org/10.1016/j.ijhydene.2016.02.074

[79] Ghungrud, S.A., Dewoolkar, K.D. and Vaidya, P.D. (2019) Cerium-Promoted Bi-Functional Hybrid Materials Made of Ni, Co and Hydrotalcite for Sorption-Enhanced Steam Methane Reforming (SESMR). International Journal of Hydrogen Energy, 44, 694-706. https://doi.org/10.1016/j.ijhydene.2018.11.002

[80] Fasolini, A., Abate, S., Barbera, D., Centi, G. and Basile, F. (2019) Pure $\mathrm{H}_{2}$ Production by Methane Oxy-Reforming over Rh-Mg-Al Hydrotalcite-Derived Catalysts Coupled with a Pd Membrane. Applied Catalysis A: General, 581, 91-102. https://doi.org/10.1016/j.apcata.2019.05.024

[81] Li, P., Yu, F., Altaf, N., Zhu, M., Li, J., Dai, B., et al. (2018) Two-Dimensional Layered Double Hydroxides for Reactions of Methanation and Methane Reforming in C1 Chemistry. Materials, 11, 221. https://doi.org/10.3390/ma11020221

[82] Thangaraj, B., Solomon, P.R., Muniyandi, B., Ranganathan, S. and Lin, L. (2018) Catalysis in Biodiesel Production-A Review. Clean Energy, 3, 2-23. https://doi.org/10.1093/ce/zky020

[83] Yu, J.J., Cheng, J., Ma, C.Y., Wang, H.L., Li, L.D., Hao, Z.P., et al. (2009) $\mathrm{NO}_{\mathrm{x}}$ Decomposition, Storage and Reduction over Novel Mixed Oxide Catalysts Derived from Hydrotalcite-Like Compounds. Journal of Colloid and Interface Science, 333, 423-430. https://doi.org/10.1016/j.jcis.2009.02.022

[84] Yong, Z. and Rodrigues, A.E. (2002) Hydrotalcite-Like Compounds as Adsorbents for Carbon Dioxide. Energy Conversion and Management, 43, 1865-1876. https://doi.org/10.1016/S0196-8904(01)00125-X

[85] Cruz-Hernández, A., Mendoza-Nieto, J.A. and Pfeiffer, H. (2017) NiOCaO Materials as Promising Catalysts for Hydrogen Production through Carbon Dioxide Capture and Subsequent Dry Methane Reforming. Journal of Energy Chemistry, 26, 942-947. https://doi.org/10.1016/j.jechem.2017.07.002

[86] Yamaguchi, A. and Iglesia, E. (2010) Catalytic Activation and Reforming of Methane on Supported Palladium Clusters. Journal of Catalysis, 274, 52-63. https://doi.org/10.1016/j.jcat.2010.06.001

[87] Wei, J. and Iglesia, E. (2004) Isotopic and Kinetic Assessment of the Mechanism of Reactions of $\mathrm{CH}_{4}$ with $\mathrm{CO}_{2}$ or $\mathrm{H}_{2} \mathrm{O}$ to Form Synthesis Gas and Carbon on Nickel Catalysts. Journal of Catalysis, 224, 370-383. https://doi.org/10.1016/j.jcat.2004.02.032

[88] Djaidja, A., Libs, S., Kiennemann, A. and Barama, A. (2006) Characterization and Activity in Dry Reforming of Methane on $\mathrm{NiMg} / \mathrm{Al}$ and $\mathrm{Ni} / \mathrm{MgO}$ Catalysts. Catalysis Today, 113, 194-200. https://doi.org/10.1016/j.cattod.2005.11.066

[89] Mohamad, H. (2018) A Mini-Review on $\mathrm{CO}_{2}$ Reforming of Methane. Progress in Petrochemical Science, 2, 161-165. https://doi.org/10.31031/PPS.2018.02.000532

[90] Fan, M.S., Abdullah, A.Z. and Bhatia, S. (2009) Catalytic Technology for Carbon Dioxide Reforming of Methane to Synthesis Gas. ChemCatChem, 1, 192-208. https://doi.org/10.1002/cctc.200900025

[91] Ojeda-Niño, O.H., Gracia, F. and Daza, C. (2019) Role of Pr on Ni-Mg-Al Mixed Oxides Synthesized by Microwave-Assisted Self-Combustion for Dry Reforming of Methane. Industrial \& Engineering Chemistry Research, 58, 7909-7921. https://doi.org/10.1021/acs.iecr.9b00557 
[92] Świrk, K., Rønning, M., Motak, M., Beaunier, P., Da Costa, P. and Grzybek, T. (2019) Ce- and Y-Modified Double-Layered Hydroxides as Catalysts for Dry Reforming of Methane: On the Effect of Yttrium Promotion. Catalysts, 9, 56. https://doi.org/10.3390/catal9010056

[93] Wierzbicki, D., Moreno, M.V., Ognier, S., Motak, M., Grzybek, T., Da Costa, P., et al. (2020) Ni-Fe Layered Double Hydroxide Derived Catalysts for Non-Plasma and DBD Plasma-Assisted $\mathrm{CO}_{2}$ Methanation. International Journal of Hydrogen Energy, 45, 10423-10432. https://doi.org/10.1016/j.ijhydene.2019.06.095

[94] Guo, Y., Lu, J., Liu, Q., Bai, X., Gao, L., Tu, W., et al. (2018) Carbon Dioxide Reforming of Methane over Cobalt Catalysts Supported on Hydrotalcite and Metal Oxides. Catalysis Communications, 116, 81-84. https://doi.org/10.1016/j.catcom.2018.08.017

[95] Li, D., Xu, S., Song, K., Chen, C., Zhan, Y. and Jiang, L. (2018) Hydrotalcite-Derived $\mathrm{Co} / \mathrm{Mg}(\mathrm{Al}) \mathrm{O}$ as a Stable and Coke-Resistant Catalyst for Low-Temperature Carbon Dioxide Reforming of Methane. Applied Catalysis A: General, 552, 21-29. https://doi.org/10.1016/j.apcata.2017.12.022

[96] Niu, J., Liland, S.E., Yang, J., Rout, K.R., Ran, J. and Chen, D. (2019) Effect of Oxide Additives on the Hydrotalcite Derived Ni Catalysts for $\mathrm{CO}_{2}$ Reforming of Methane. Chemical Engineering Journal, 377, Article ID: 119763. https://doi.org/10.1016/j.cej.2018.08.149

[97] Świrk, K., Galvez, M.E., Motak, M., Grzybek, T., Rønning, M. and Da Costa, P. (2018) Yttrium Promoted Ni-Based Double-Layered Hydroxides for Dry Methane Reforming. Journal of $\mathrm{CO}_{2}$ Utilization, 27, 247-258. https://doi.org/10.1016/j.jcou.2018.08.004

[98] Aider, N., Touahra, F., Bali, F., Djebarri, B., Lerari, D., Bachari, K., et al. (2018) Improvement of Catalytic Stability and Carbon Resistance in the Process of $\mathrm{CO}_{2} \mathrm{Re}-$ forming of Methane by CoAl and CoFe Hydrotalcite-Derived Catalysts. International Journal of Hydrogen Energy, 43, 8256-8266. https://doi.org/10.1016/j.ijhydene.2018.03.118

[99] Świrk, K., Galvez, M.E., Motak, M., Grzybek, T., Rønning, M. and Da Costa, P. (2018) Dry Reforming of Methane over Zr- and Y-Modified Ni/Mg/Al Double-Layered Hydroxides. Catalysis Communications, 117, 26-32.

https://doi.org/10.1016/j.catcom.2018.08.024

[100] Kalai, D.Y., Stangeland, K., Jin, Y. and Yu, Z. (2018) Active and Stable Hydrotalcite Derived Ni Catalysts for $\mathrm{CO}_{2}$ Reforming of Methane: Comparison with Catalysts by Incipient Wetness. Journal of $\mathrm{CO}_{2}$ Utilization, 25, 346-355. https://doi.org/10.1016/j.jcou.2017.12.018

[101] Dahdah, E., Rached, J.A., Aouad, S., Gennequin, C., Tidahy, H., Estephane, J., et al. (2017) $\mathrm{CO}_{2}$ Reforming of Methane over $\mathrm{Ni}_{x} \mathrm{Mg}_{6-\mathrm{x}} \mathrm{Al}_{2}$ Catalysts: Effect of Lanthanum Doping on Catalytic Activity and Stability. International Journal of Hydrogen Energy, 42, 12808-12817. https://doi.org/10.1016/j.ijhydene.2017.01.197

[102] Kalai, D.Y., Stangeland, K., Li, H. and Yu, Z. (2017) The Effect of La on the Hydrotalcite Derived Ni Catalysts for Dry Reforming of Methane. Energy Procedia, 142, 3721-3726. https://doi.org/10.1016/j.egypro.2017.12.267

[103] Dębek, R., Motak, M., Galvez, M.E., Da Costa, P. and Grzybek, T. (2017) Catalytic Activity of Hydrotalcite-Derived Catalysts in the Dry Reforming of Methane: On the Effect of Ce Promotion and Feed Gas Composition. Reaction Kinetics, Mechanisms and Catalysis, 121, 185-208. https://doi.org/10.1007/s11144-017-1167-1

[104] Dębek, R., Motak, M., Galvez, M.E., Grzybek, T. and Da Costa, P. (2018) Promotion Effect of Zirconia on $\mathrm{Mg}(\mathrm{Ni}, \mathrm{Al}) \mathrm{O}$ Mixed Oxides Derived from Hydrotalcites in $\mathrm{CO}_{2}$ 
Methane Reforming. Applied Catalysis B: Environmental, 223, 36-46. https://doi.org/10.1016/j.apcatb.2017.06.024

[105] Wierzbicki, D., Baran, R., Dębek, R., Motak, M., Grzybek, T., Gálvez, M.E., et al. (2017) The Influence of Nickel Content on the Performance of Hydrotalcite-Derived Catalysts in $\mathrm{CO}_{2}$ Methanation Reaction. International Journal of Hydrogen Energy, 42, 23548-23555. https://doi.org/10.1016/j.ijhydene.2017.02.148

[106] Zhu, Y., Zhang, S., Chen, B., Zhang, Z. and Shi, C. (2016) Effect of Mg/Al Ratio of $\mathrm{NiMgAl}$ Mixed Oxide Catalyst Derived from Hydrotalcite for Carbon Dioxide Reforming of Methane. Catalysis Today, 264, 163-170. https://doi.org/10.1016/j.cattod.2015.07.037

[107] Touahra, F., Sehailia, M., Ketir, W., Bachari, K., Chebout, R., Trari, M., et al. (2016) Effect of the Ni/Al Ratio of Hydrotalcite-Type Catalysts on Their Performance in the Methane Dry Reforming Process. Applied Petrochemical Research, 6, 1-13. https://doi.org/10.1007/s13203-015-0109-y

[108] Ren, H.-P., Song, Y.-H., Wang, W., Chen, J.-G., Cheng, J., Jiang, J., et al. (2015) Insights into $\mathrm{CeO}_{2}$-Modified Ni-Mg-Al Oxides for Pressurized Carbon Dioxide Reforming of Methane. Chemical Engineering Journal, 259, 581-593. https://doi.org/10.1016/j.cej.2014.08.029

[109] Lin, X., Li, R., Lu, M., Chen, C., Li, D., Zhan, Y., et al. (2015) Carbon Dioxide Reforming of Methane over Ni Catalysts Prepared from Ni-Mg-Al Layered Double Hydroxides: Influence of Ni Loadings. Fuel, 162, 271-280.

https://doi.org/10.1016/j.fuel.2015.09.021

[110] Xu, J., Yeung, C.M., Ni, J., Meunier, F., Acerbi, N., Fowles, M., et al. (2008) Methane Steam Reforming for Hydrogen Production Using Low Water-Ratios without Carbon Formation over Ceria Coated Ni Catalysts. Applied Catalysis A: General, 345, 119-127. https://doi.org/10.1016/j.apcata.2008.02.044

[111] Abbas, H.F. and Daud, W.W. (2010) Hydrogen Production by Methane Decomposition: A Review. International Journal of Hydrogen Energy, 35, 1160-1190. https://doi.org/10.1016/j.ijhydene.2009.11.036

[112] Christensen, K.O., Chen, D., Lødeng, R. and Holmen, A. (2006) Effect of Supports and Ni Crystal Size on Carbon Formation and Sintering during Steam Methane Reforming. Applied Catalysis A: General, 314, 9-22. https://doi.org/10.1016/j.apcata.2006.07.028

[113] Dewoolkar, K.D. and Vaidya, P.D. (2017) Tailored Ce- and Zr-Doped Ni/Hydrotalcite Materials for Superior Sorption-Enhanced Steam Methane Reforming. International Journal of Hydrogen Energy, 42, 21762-21774. https://doi.org/10.1016/j.ijhydene.2017.06.235

[114] Qi, Y., Cheng, Z. and Zhou, Z. (2015) Steam Reforming of Methane over Ni Catalysts Prepared from Hydrotalcite-Type Precursors: Catalytic Activity and Reaction Kinetics. Chinese Journal of Chemical Engineering, 23, 76-85. https://doi.org/10.1016/j.cjche.2013.11.002

[115] Dewoolkar, K.D. and Vaidya, P.D. (2015) Improved Hydrogen Production by Sorption-Enhanced Steam Methane Reforming over Hydrotalcite- and Calcium-Based Hybrid Materials. Energy \& Fuels, 29, 3870-3878. https://doi.org/10.1021/acs.energyfuels.5b00584

[116] Kim, N.Y., Yang, E.-H., Lim, S.-S., Jung, J.S., Lee, J.-S., Hong, G.H., et al. (2015) Hydrogen Production by Steam Reforming of Methane over Mixed Ni/MgAl + $\mathrm{CrFe}_{3} \mathrm{O}_{4}$ Catalysts. International Journal of Hydrogen Energy, 40, 11848-11854. https://doi.org/10.1016/j.ijhydene.2015.06.104 
[117] Velasco, J.A., Fernandez, C., Lopez, L., Cabrera, S., Boutonnet, M. and Järås, S. (2015) Catalytic Partial Oxidation of Methane over Nickel and Ruthenium Based Catalysts under Low $\mathrm{O}_{2} / \mathrm{CH}_{4}$ Ratios and with Addition of Steam. Fuel, 153, 192-201. https://doi.org/10.1016/j.fuel.2015.03.009

[118] Nawfal, M., Gennequin, C., Labaki, M., Nsouli, B., Aboukaïs, A. and Abi-Aad, E. (2015) Hydrogen Production by Methane Steam Reforming over Ru Supported on $\mathrm{Ni}-\mathrm{Mg}$-Al Mixed Oxides Prepared via Hydrotalcite Route. International Journal of Hydrogen Energy, 40, 1269-1277. https://doi.org/10.1016/j.ijhydene.2014.09.166

[119] Broda, M., Manovic, V., Imtiaz, Q., Kierzkowska, A.M., Anthony, E.J. and Müller, C.R. (2013) High-Purity Hydrogen via the Sorption-Enhanced Steam Methane Reforming Reaction over a Synthetic CaO-Based Sorbent and a Ni Catalyst. Environmental Science \& Technology, 47, 6007-6014.

https://doi.org/10.1021/es305113p

[120] Chanburanasiri, N., Ribeiro, A.M., Rodrigues, A.E., Arpornwichanop, A., Laosiripojana, N., Praserthdam, P., et al. (2011) Hydrogen Production via Sorption Enhanced Steam Methane Reforming Process Using Ni/CaO Multifunctional Catalyst. Industrial \& Engineering Chemistry Research, 50, 13662-13671. https://doi.org/10.1021/ie201226j

[121] Zhan, Y., Li, D., Nishida, K., Shishido, T., Oumi, Y., Sano, T., et al. (2009) Preparation of "Intelligent" $\mathrm{Pt} / \mathrm{Ni} / \mathrm{Mg}(\mathrm{Al}) \mathrm{O}$ Catalysts Starting from Commercial $\mathrm{Mg}-\mathrm{Al}$ LDHs for Daily Start-Up and Shut-Down Steam Reforming of Methane. Applied Clay Science, 45, 147-154. https://doi.org/10.1016/j.clay.2009.05.002

[122] Joensen, F. and Rostrup-Nielsen, J.R. (2002) Conversion of Hydrocarbons and Alcohols for Fuel Cells. Journal of Power Sources, 105, 195-201. https://doi.org/10.1016/S0378-7753(01)00939-9

[123] Behrens, M. and Armbrüster, M. (2012) Methanol Steam Reforming. In: Guczi, L. and Erdôhelyi, A., Eds., Catalysis for Alternative Energy Generation, Springer, New York, 175-235. https://doi.org/10.1007/978-1-4614-0344-9 5

[124] Turco, M., Bagnasco, G., Costantino, U., Marmottini, F., Montanari, T., Ramis, G., et al. (2004) Production of Hydrogen from Oxidative Steam Reforming of Methanol: II. Catalytic Activity and Reaction Mechanism on $\mathrm{Cu} / \mathrm{ZnO} / \mathrm{Al}_{2} \mathrm{O}_{3}$ Hydrotalcite-Derived Catalysts. Journal of Catalysis, 228, 56-65. https://doi.org/10.1016/S0021-9517(04)00411-7

[125] Palo, D.R., Dagle, R.A. and Holladay, J.D. (2007) Methanol Steam Reforming for Hydrogen Production. Chemical Reviews, 107, 3992-4021. https://doi.org/10.1021/cr050198b

[126] Tang, Y., Liu, Y., Zhu, P., Xue, Q., Chen, L. and Lu, Y. (2009) High-Performance HTLcs-Derived CuZnAl Catalysts for Hydrogen Production via Methanol Steam Reforming. AIChE Journal, 55, 1217-1228. https://doi.org/10.1002/aic.11753

[127] Yang, S.-Q., He, J.-P., Zhang, N., Sui, X.-W., Zhang, L. and Yang, Z.-X. (2018) Effect of Rare-Earth Element Modification on the Performance of $\mathrm{Cu} / \mathrm{ZnAl}$ Catalysts Derived from Hydrotalcite Precursor in Methanol Steam Reforming. Journal of Fuel Chemistry and Technology, 46, 179-188. https://doi.org/10.1016/S1872-5813(18)30010-0

[128] He, J., Yang, Z., Zhang, L., Li, Y. and Pan, L. (2017) Cu Supported on ZnAl-LDHs Precursor Prepared by In-Situ Synthesis Method on $\gamma-\mathrm{Al}_{2} \mathrm{O}_{3}$ as Catalytic Material with High Catalytic Activity for Methanol Steam Reforming. International Journal of Hydrogen Energy, 42, 9930-9937. https://doi.org/10.1016/j.ijhydene.2017.01.229

[129] Kim, W., Mohaideen, K.K., Seo, D.J. and Yoon, W.L. (2017) Methanol-Steam Re- 
forming Reaction over Cu-Al-Based Catalysts Derived from Layered Double Hydroxides. International Journal of Hydrogen Energy, 42, 2081-2087.

https://doi.org/10.1016/j.ijhydene.2016.11.014

[130] Wu, X. and Wu, S. (2015) Production of High-Purity Hydrogen by Sorption-Enhanced Steam Reforming Process of Methanol. Journal of Energy Chemistry, 24, 315-321. https://doi.org/10.1016/S2095-4956(15)60317-5

[131] Hammoud, D., Gennequin, C., Aboukaïs, A. and Aad, E.A. (2015) Steam Reforming of Methanol over $x \% \mathrm{Cu} / \mathrm{Zn}-\mathrm{Al} 400500$ Based Catalysts for Production of Hydrogen: Preparation by Adopting Memory Effect of Hydrotalcite and Behavior Evaluation. International Journal of Hydrogen Energy, 40, 1283-1297.

https://doi.org/10.1016/j.ijhydene.2014.09.080

[132] Kühl, S., Friedrich, M., Armbrüster, M. and Behrens, M. (2012) Cu, Zn, Al Layered Double Hydroxides as Precursors for Copper Catalysts in Methanol Steam Reforming- $\mathrm{pH}$-Controlled Synthesis by Microemulsion Technique. Journal of Materials Chemistry, 22, 9632-9638. https://doi.org/10.1039/c2jm16138a

[133] Ota, A., Kunkes, E.L., Kasatkin, I., Groppo, E., Ferri, D., Poceiro, B., et al. (2012) Comparative Study of Hydrotalcite-Derived Supported $\mathrm{Pd}_{2} \mathrm{Ga}$ and $\mathrm{PdZn}$ Intermetallic Nanoparticles as Methanol Synthesis and Methanol Steam Reforming Catalysts. Journal of Catalysis, 293, 27-38. https://doi.org/10.1016/j.jcat.2012.05.020

[134] Espinal, R., Taboada, E., Molins, E., Chimentao, R.J., Medina, F. and Llorca, J. (2012) Cobalt Hydrotalcite for the Steam Reforming of Ethanol with Scarce Carbon Production. RSC Advances, 2, 2946-2956. https://doi.org/10.1039/c2ra00936f

[135] Coleman, L., Epling, W., Hudgins, R. and Croiset, E. (2009) Ni/Mg-Al Mixed Oxide Catalyst for the Steam Reforming of Ethanol. Applied Catalysis A: General, 363, 52-63. https://doi.org/10.1016/j.apcata.2009.04.032

[136] Casanovas, A., Saint-Gerons, M., Griffon, F. and Llorca, J. (2008) Autothermal Generation of Hydrogen from Ethanol in a Microreactor. International Journal of Hydrogen Energy, 33, 1827-1833. https://doi.org/10.1016/j.ijhydene.2008.01.018

[137] Resini, C., Montanari, T., Barattini, L., Ramis, G., Busca, G., Presto, S., et al. (2009) Hydrogen Production by Ethanol Steam Reforming over Ni Catalysts Derived from Hydrotalcite-Like Precursors: Catalyst Characterization, Catalytic Activity and Reaction Path. Applied Catalysis A: General, 355, 83-93.

https://doi.org/10.1016/j.apcata.2008.11.029

[138] Cruz, I.O., Ribeiro, N.F., Aranda, D.A. and Souza, M.M. (2008) Hydrogen Production by Aqueous-Phase Reforming of Ethanol over Nickel Catalysts Prepared from Hydrotalcite Precursors. Catalysis Communications, 9, 2606-2611. https://doi.org/10.1016/j.catcom.2008.07.031

[139] Contreras, J., Tapia, C., Fuentes, G., Nuño, L., Quintana, B., Salmones, J., et al. (2014) Equilibrium Composition of Ethanol Steam Reforming Reaction to Produce $\mathrm{H}_{2}$ Applied to $\mathrm{Ni}$, Co and $\mathrm{Pt} / \mathrm{Hydrotalcite-} \mathrm{WO}_{\mathrm{x}}$ Catalysts. International Journal of Hydrogen Energy, 39, 16608-16618. https://doi.org/10.1016/j.ijhydene.2014.04.080

[140] He, L., Berntsen, H., Ochoa-Fernández, E., Walmsley, J.C., Blekkan, E.A. and Chen, D. (2009) Co-Ni Catalysts Derived from Hydrotalcite-Like Materials for Hydrogen Production by Ethanol Steam Reforming. Topics in Catalysis, 52, 206-217. https://doi.org/10.1007/s11244-008-9157-1

[141] Muñoz, M., Moreno, S. and Molina, R. (2017) Oxidative Steam Reforming of Ethanol (OSRE) over Stable NiCo-MgAl Catalysts by Microwave or Sonication Assisted Coprecipitation. International Journal of Hydrogen Energy, 42, 12284-12294. https://doi.org/10.1016/j.ijhydene.2017.03.090 
[142] Espitia-Sibaja, M., Muñoz, M., Moreno, S. and Molina, R. (2017) Effects of the Cobalt Content of Catalysts Prepared from Hydrotalcites Synthesized by Ultrasound-Assisted Coprecipitation on Hydrogen Production by Oxidative Steam Reforming of Ethanol (OSRE). Fuel, 194, 7-16.

https://doi.org/10.1016/j.fuel.2016.12.086

[143] Espinal, R., Anzola, A., Adrover, E., Roig, M., Chimentao, R., Medina, F., et al. (2014) Durable Ethanol Steam Reforming in a Catalytic Membrane Reactor at Moderate Temperature over Cobalt Hydrotalcite. International Journal of Hydrogen Energy, 39, 10902-10910. https://doi.org/10.1016/j.ijhydene.2014.05.127

[144] Fang, W., Paul, S., Capron, M., Dumeignil, F. and Jalowiecki-Duhamel, L. (2014) Hydrogen Production from Bioethanol Catalyzed by $\mathrm{Ni}_{X} \mathrm{Mg}_{2} \mathrm{AlO}_{\mathrm{Y}}$ ex-Hydrotalcite Catalysts. Applied Catalysis B: Environmental, 152, 370-382.

https://doi.org/10.1016/j.apcatb.2014.01.056

[145] Zeng, G., Shao, J., Gu, R. and Li, Y. (2014) Facile Fabrication of a Highly Active Shell-Core LaNi(Mg,Al)O $\mathrm{O}_{3} @ \mathrm{Mg}-\mathrm{Al}$ Catalyst for Ethanol Steam Reforming. Catalysis Today, 233, 31-37. https://doi.org/10.1016/j.cattod.2014.02.024

[146] Zeng, G., Gu, R. and Li, Y. (2013) The Preparation and Catalytic Behavior of a Shell-Core Ni/Mg-Al Catalyst for Ethanol Steam Reforming. International Journal of Hydrogen Energy, 38, 11256-11267. https://doi.org/10.1016/j.ijhydene.2013.06.058

[147] Abelló, S., Bolshak, E. and Montane, D. (2013) Ni-Fe Catalysts Derived from Hydrotalcite-Like Precursors for Hydrogen Production by Ethanol Steam Reforming. Applied Catalysis A: General, 450, 261-274. https://doi.org/10.1016/j.apcata.2012.10.035

[148] Bolshak, E., Abelló, S. and Montané, D. (2013) Ethanol Steam Reforming over $\mathrm{Ni}-\mathrm{Fe}$-Based Hydrotalcites: Effect of Iron Content and Reaction Temperature. International Journal of Hydrogen Energy, 38, 5594-5604. https://doi.org/10.1016/j.ijhydene.2013.02.077

[149] Cunha, A., Wu, Y.-J., Santos, J. and Rodrigues, A. (2013) Sorption Enhanced Steam Reforming of Ethanol on Hydrotalcite-Like Compounds Impregnated with Active Copper. Chemical Engineering Research and Design, 91, 581-592. https://doi.org/10.1016/j.cherd.2012.09.015

[150] Moura, J.S., Souza, M.O., Bellido, J.D.A., Assaf, E.M., Opportus, M., Reyes, P., et al. (2012) Ethanol Steam Reforming over Rhodium and Cobalt-Based Catalysts: Effect of the Support. International Journal of Hydrogen Energy, 37, 3213-3224. https://doi.org/10.1016/j.ijhydene.2011.10.112

[151] Guil-López, R., Navarro, R., Peña, M. and Fierro, J. (2011) Hydrogen Production by Oxidative Ethanol Reforming on $\mathrm{Co}, \mathrm{Ni}$ and $\mathrm{Cu} e x$-Hydrotalcite Catalysts. International Journal of Hydrogen Energy, 36, 1512-1523. https://doi.org/10.1016/j.ijhydene.2010.10.084

[152] Zeng, G., Liu, Q., Gu, R., Zhang, L. and Li, Y. (2011) Synergy Effect of MgO and $\mathrm{ZnO}$ in a Ni/Mg-Zn-Al Catalyst during Ethanol Steam Reforming for $\mathrm{H}_{2}$-Rich Gas Production. Catalysis Today, 178, 206-213. https://doi.org/10.1016/j.cattod.2011.07.036

[153] Busca, G., Costantino, U., Montanari, T., Ramis, G., Resini, C. and Sisani, M. (2010) Nickel versus Cobalt Catalysts for Hydrogen Production by Ethanol Steam Reforming: Ni-Co-Zn-Al Catalysts from Hydrotalcite-Like Precursors. International Journal of Hydrogen Energy, 35, 5356-5366.

https://doi.org/10.1016/j.ijhydene.2010.02.124

[154] Lucrédio, A.F., Bellido, J.D.A. and Assaf, E.M. (2010) Effects of Adding La and Ce 
to Hydrotalcite-Type $\mathrm{Ni} / \mathrm{Mg} / \mathrm{Al}$ Catalyst Precursors on Ethanol Steam Reforming Reactions. Applied Catalysis A: General, 388, 77-85. https://doi.org/10.1016/j.apcata.2010.08.026

[155] Lavoie, J.-M. (2014) Review on Dry Reforming of Methane, a Potentially More Environmentally-Friendly Approach to the Increasing Natural Gas Exploitation. Frontiers in Chemistry, 2, 81.

[156] Trimm, D.L. (1998) The Steam Reforming of Natural Gas: Problems and Some Solutions. Studies in Surface Science and Catalysis, 36, 39-50. https://doi.org/10.1016/S0167-2991(09)60498-5

[157] Jens, S. (2006) Four Challenges for Ni-Steam Reforming Catalysts. Catalysis Today, 111, 103-110. https://doi.org/10.1016/j.cattod.2005.10.002

[158] Bilal, Y. (2016) Hydrotalcite Based Ni-Co Bi-Metallic Catalysts for Steam Reforming of Methane. Dissertation, Norwegian University of Science and Technology, 5, 23-34.

[159] Xu, X.H., Shuai, K.P. and Xu, B. (2007) Review on Copper and Palladium Based Catalysts for Methanol Steam Reforming to Produce Hydrogen. Catalysts, 7, 183. https://doi.org/10.3390/catal7060183

[160] Iulianelli, A., Ribeirinha, P., Mendes, A. and Basile, A. (2014) Methanol Steam Reforming for Hydrogen Generation via Conventional and Membrane Reactors: A Review. Renewable and Sustainable Energy Reviews, 29, 355-368. https://doi.org/10.1016/j.rser.2013.08.032

[161] Narasimharao, K., Lee, A. and Wilson, K. (2007) Catalysts in Production of Biodiesel: A Review. Journal of Biobased Materials and Bioenergy, 1, 19-30. https://doi.org/10.1166/jbmb.2007.1976

[162] Zhang, B., Lin, L., Zuang, J.P., Liu, Y., Peng, L.C. and Jiang, L.F. (2010) Hydrogenation of Ethyl Acetate to Ethanol over Ni-Based Catalysts Obtained from Ni/Al Hydrotalcite-Like Compounds. Molecules, 15, 5139-5152. https://doi.org/10.3390/molecules15085139

[163] Ping, X.Z., Zhang, J., Adebajo, M.O., Zhang, H. and Zhou, C. (2011) Catalytic Applications of Layered Double Hydroxides and Derivatives. Applied Clay Science, 53, 139-150. https://doi.org/10.1016/j.clay.2011.02.007

[164] Tichit, D., Lhouty, M.H., Guida, A., Chiche, B.H., Francois, F., Auroux, A., Bartalini, D. and Garrone, E. (1995) Textural Properties and Catalytic Activity of Hydrotalcites. Journal of Catalyst, 151, 50-59. https://doi.org/10.1006/jcat.1995.1007

[165] Reichle, W.T., Kang, S.Y. and Everhardt, D.S. (1986) The Nature of the Thermal Decomposition of a Catalytically Active Anionic Clay Mineral. Journal of Catalyst, 101, 352-359. https://doi.org/10.1016/0021-9517(86)90262-9 